\title{
Rethinking Environmental Racism: White Privilege and Urban Development in Southern California
}

\author{
Laura Pulido \\ 2000. Annals of the Association of American Geographers 90(1), 12-40. ${ }^{1}$
}

The concept of environmental racism - the idea that nonwhites are disproportionately exposed to pollution - emerged more than ten years ago with the United Church of Christ's study, Toxic Waste and Race in the United States (1987). Given the social, ecological, and health implications of environmental hazards, geographers have explored environmental racism with the goal of contributing to better policymaking. Studies have sought to determine if inequalities exist and the reasons for such disparities, and to make recommendations (Cutter, 1995). While these are obviously important research contributions, studying environmental racism is important for an additional reason: it helps us understand racism.

Although the study of racial inequality is not new to geographers (Anderson, 1987; Gilmore, 1998; Jackson and Penrose, 1994; Kobayashi and Peake, 1994; S. Smith, 1993; Woods, 1998), environmental racism offers us new insights into the subject, particularly its spatiality. Unfortunately, scholars of environmental racism have not seriously problematized racism, opting instead for a de facto conception based on malicious, individual acts. There are several problems with this approach. First, by reducing racism to a hostile, discriminatory act, many researchers, with the notable exception of Bullard (1990), miss the role of structural and hegemonic forms of racism in contributing to such inequalities. Indeed, structural racism has been the dominant mode of analysis in other substantive areas of social research, such as

\footnotetext{
${ }^{1}$ Reprinted with permission from Wiley-Blackwell Publishing and Laura Pulido.
} 
residential segregation (Massey and Denton, 1993) and employment patterns (Kirschenman and Neckerman, 1991), since at least Myrdal's An American Dilemma (1944). Not only has the environmental racism literature become estranged from social science discussions of race, but, in the case of urban-based research, it is divorced from contemporary urban geography. A second and related concern is that racism is not conceptualized as the dynamic sociospatial process that it is. Because racism is understood as a discrete act that may be spatially expressed, it is not seen as a sociospatial relation both constitutive of the city and produced by it. As a result, the spatiality of racism is not understood, particularly the relationship between places. Yet pollution concentrations are inevitably the product of relationships between distinct places, including industrial zones, affluent suburbs, working-class suburbs, and downtown areas, all of which are racialized. A final problem with a narrow understanding of racism is that it limits claims, thereby reproducing a racist social order. By defining racism so narrowly, racial inequalities that cannot be attributed directly to a hostile, discriminatory act are not acknowledged as such, but perhaps as evidence of individual deficiencies or choices. Yet if we wish to create a more just society, we must acknowledge the breadth and depth of racism.

In this paper, I investigate how racism is conceptualized in the environmental racism literature. Using Los Angeles as a case study (Figure 1), I apply an alternative concept of racism, white privilege, in addition to more common understandings of discrimination, to explain disparate environmental patterns. I identify three specific issues that contribute to a narrow conception of racism: first, an emphasis on individual facility siting; second, the role of intentionality; and third, an uncritical approach to scale. Typically, a study may acknowledge environmental inequity if nonwhites are disproportionately exposed to pollution, but environmental racism is only conceded if malicious intent on the part of decision makers can be proven. ${ }^{2}$

I argue that the emphasis on siting, while obviously important, must be located in larger urban processes, and thus requires us to "jump scales" in our analysis (N. Smith, 1993). This is especially true given recent findings that pollution concentrations are closely associated with industrial land use (Anderton et al., 1994b; Baden and Coursey, 1997; Boer et al., 1997; Colten, 1986; Pulido et al., 1996). This research recasts issues of intentionality and scale, as it requires us to examine the production of

${ }^{2}$ A word on terminology is in order. In early studies, the term "environmental racism" was used to denote disparate patterns. Over time, the term "environmental equity" became popular as it was more inclusive, encompassing both racial and economic disparities. Many activists, however, also saw it as an effort to depoliticize the antiracist consciousness underlying the movement. Moreover, as Heiman (1990) has pointed out, environmental (in)equity implies the problem is with the allocation of pollution and environmental hazards, rather than with a particular economic system. Activists eventually adopted the term "environmental justice," as it was inclusive and offered a more politicized conception of the problem. While supportive of the environmental justice movement, I use the term environmental racism to highlight racial disparities. At times, I will use "environmental inequities" to refer to allocation issues. 
industrial zones, their relation to other parts of the metropolis, and the potentially racist nature of the processes by which these patterns evolved.

Because of the limitations of the prevailing approach to racism, I seek to broaden our understanding through a complementary conception of racism: white privilege. My understanding of racism begins from the premise that race is a material/discursive formation. Because race exists in various realms, racial meanings are embedded in our language, psyche, and social structures. These racial meanings are both constitutive of racial hierarchies and informed by them. Thus, it would be impossible for our social practices and structures not to reflect these racial understandings. Given the pervasive nature of race, the belief that racism can be reduced to hostile, discriminatory acts strains logic. For instance, few can dispute that U[nited] S[tates] cities are highly segregated. Can we attribute this simply to discriminatory lenders and landlords? No. Residential segregation results from a diversity of racisms. Moreover, there is growing evidence that racial responses are often unconscious, the result of lifelong inculcation (Devine, 1989; Lawrence, 1987). Thus, focusing exclusively on discriminatory acts ignores the fact that all places are racialized, and that race informs all places. Clearly, our preoccupation with discrete discriminatory acts ignores vast dimensions of racism.

A focus on white privilege enables us to develop a more structural, less conscious, and more deeply historicized understanding of racism. It differs from a hostile, individual, discriminatory act, in that it refers to the privileges and benefits that accrue to white people by virtue of their whiteness. Because whiteness is rarely problematized by whites, white privilege is scarcely acknowledged. According to George Lipsitz, "As the unmarked category against which difference is constructed, whiteness never has to speak its name, never has to acknowledge its role as an organizing principle in social and cultural relations" $(1995,369)$. White privilege is thus an attempt to name a social system that works to the benefit of whites. White privilege, together with overt and institutionalized racism, reveals how racism shapes places. Hence, instead of asking if an incinerator was placed in a Latino community because the owner was prejudiced, I ask, why is it that whites are not comparably burdened with pollution (see Szasz and Meuser,

1997)? In the case of Los Angeles, industrialization, decentralization, and residential segregation are keys to this puzzle. Because industrial land use is highly correlated with pollution concentrations and people of color, the crucial question becomes, how did whites distance themselves from both industrial pollution and nonwhites? 


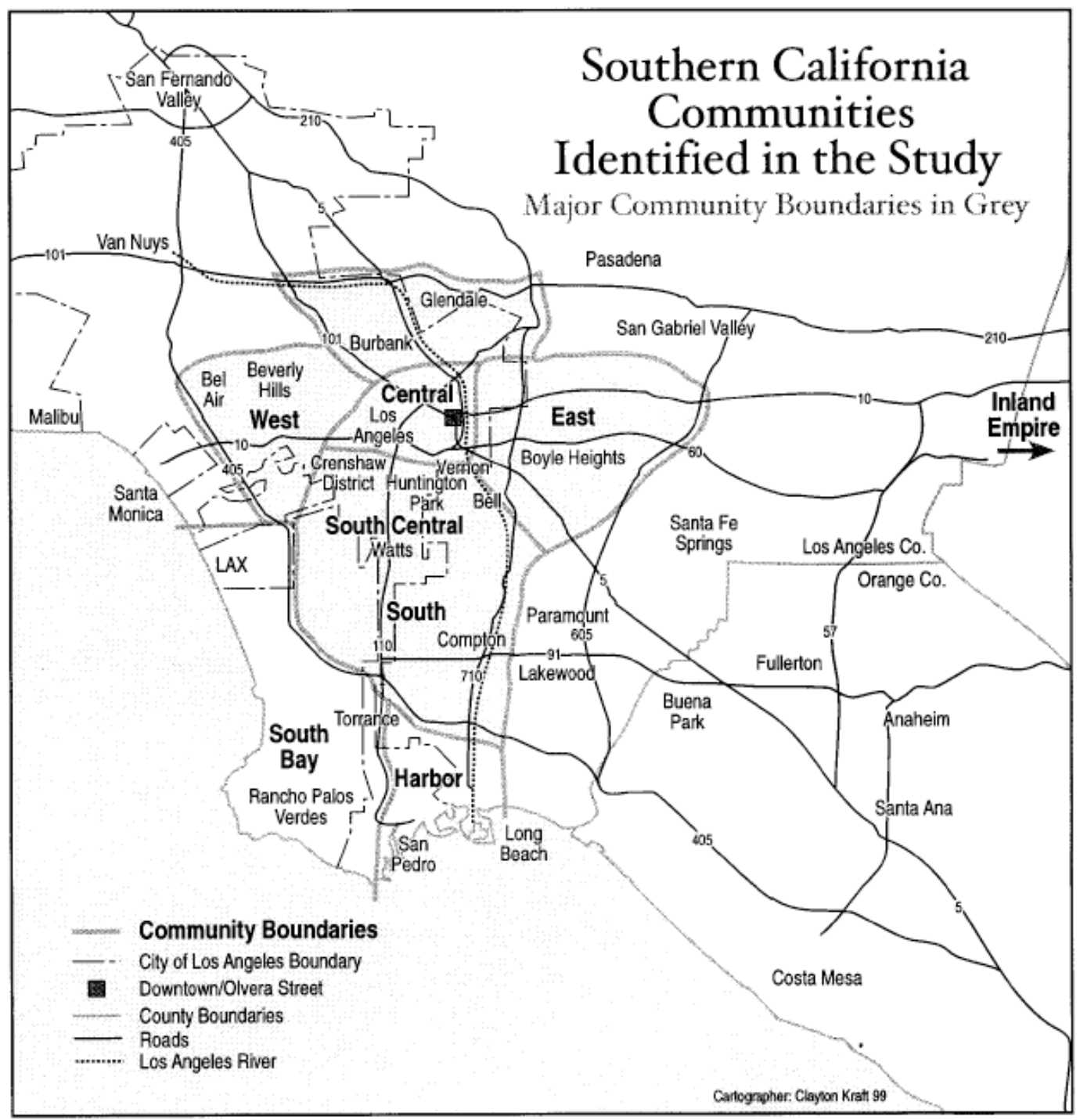

Figure 1. Los Angeles-area communities identified in this study.

This study does not attempt to prove that environmental racism exists in Los Angeles, as six studies have already done so (Boer et al., 1997; Burke, 1993; Pulido et al., 1996; Sadd et al., 1999; Szasz et al., 1993; UCC, 1987). Nor do I suggest that this particular narrative of racism, white privilege, operates in all places in the same way. Rather, my goal is to consider the larger sociospatial processes of inequality that produce environmental racism. In this paper, I first develop the concept of white privilege. Second, I review how racism and space have been conceptualized in the literature and the geography of urban environmental racism. Third, drawing on both primary and secondary sources, I examine the historical processes and their racist underpinnings that have contributed to the environmental racism we see in Los Angeles today. I conclude by summarizing my findings and their implications. 


\section{Racism and White Privilege}

A clear definition of race and white racism is in order. I employ Omi and Winant's $(1994,55)$ idea of race as "a concept which signifies and symbolizes social conflicts and interests by referring to different types of human bodies". This definition not only recognizes the physical, material, and ideological dimensions of race, but also acknowledges race as contributing to the social formation. Specifically, it allows us to see race as more than colored bodies. It enables us to recognize the pervasive and hegemonic nature of race, its multiscalar nature, and its multiple forms of existence, including ideas, words, actions, and structures. This approach to race serves as a basis for a broader and more fluid definition of white racism. I define white racism as those practices and ideologies, carried out by structures, institutions, and individuals, that reproduce racial inequality and systematically undermine the well-being of racially subordinated populations.

Because there are multiple motives and forms of racism (Cohen, 1992; Goldberg, 1993; Omi, 1992), there are various ways of analyzing racisms. In this paper, I consider only two: scale and intention. In any attempt to understand racism, scale is an important analytical tool in that it is both defined by racism and transcends it. Consider the various scales at which racism exists: the individual, the group, the institution, society, the global. While all are distinct, there is a dialectical relation between these scales. So, for instance, an individual racist act is just that, an act carried out at the level of the individual. Nonetheless, that individual is informed by regional and/or national racial discourses, and his/her act informs and reproduces racial discourses and structures at higher scales. Thus, we can focus on a particular scale, but we must always be cognizant of its relationship to other scales of racism.

A second crucial issue is the question of intent. While most social science scholars acknowledge institutional and structural racism, popular understandings focus heavily on individual malicious intent. Indeed, this trend is reflected in court rulings that have increasingly required proof of intent (e.g., Washington v. Davis) ${ }^{3}$. For many, a hostile motive is considered necessary for an action or inequality to qualify as racist. While aware of the power of hostile and malicious acts, we cannot allow their reprehensible nature to obscure the range of racist motives that exist. For instance, in this society, there are white supremacists, those who avoid people of color, and those who advocate a "color-blind" society. Each of these positions evinces a different motive. And while they may not be morally comparable, they are all racist because they systematically undermine the well-being of people of color (Delgado, 1995).

White privilege is a form of racism that both underlies and is distinct from institutional and overt racism. It underlies them in that both are predicated on

${ }^{3}$ Washington v. Davis was an employment discrimination suit in which the Court ultimately ruled that a law that produced a racially disparate impact regardless of motive is not unconstitutional. 
preserving the privileges of white people (regardless of whether agents recognize this or not). But it is also distinct in terms of intentionality. It refers to the hegemonic structures, practices, and ideologies that reproduce whites' privileged status. In this scenario, whites do not necessarily intend to hurt people of color, but because they are unaware of their white-skin privilege, and because they accrue social and economic benefits by maintaining the status quo, they inevitably do. White privilege thrives in highly racialized societies that espouse racial equality, but in which whites will not tolerate either being inconvenienced in order to achieve racial equality (Delgado, 1995; Edsall and Edsall, 1991; Lipsitz, 1998; Quadagno, 1994), or denied the full benefits of their whiteness (Harris, 1993). It is precisely because few whites are aware of the benefits they receive simply from being white and that their actions, without malicious intent, may undermine the well-being of people of color, that white privilege is so powerful and pervasive.

White privilege allows us to see how the racial order works to the benefit of whites, whether in the form of economic and political benefits (Almaguer, 1994; Harris, 1993; Ignatiev, 1995; Oliver and Shapiro, 1995), or psychological ones (Fanon, 1967; Roediger, 1991). White privilege is distinct from both white supremacy, a more blatant and acknowledged form of white dominance (Fredrickson, 1981, xi), as well as from more individual, discriminatory acts. Rather, it flourishes in relation to these other forms. Because most white people do not see themselves as having malicious intentions, and because racism is associated with malicious intent, whites can exonerate themselves of all racist tendencies, all the while ignoring their investment in white privilege. It is this ability to sever intent from outcome that allows whites to acknowledge that racism exists, yet seldom identify themselves as racists.

Evidence of white privilege abounds. It includes the degree to which whites assume ownership of this nation and its opportunities, people of color's efforts to "pass" in order to access whiteness, whites' resistance to attempts to dismantle their privilege, and, conversely, even whites' efforts to shed their privilege ${ }^{4}$. Consider the case of white resistance. White resistance to integrating schools, housing, and the workplace has all been well documented (Almaguer, 1994; Foner, 1974; Massey and Denton, 1993; Quadagno, 1994; Saxton, 1971). This resistance is hardly surprising and is justified by any number of rationales. What is important is the fact that whites resist because they feel they have something to lose. According to Lipsitz (1998), they have a "possessive investment in whiteness," meaning, whiteness pays off and whites wish to retain those benefits. Legal scholar Cheryl Harris has observed,

The set of assumptions, privileges, and benefits that accompany the status of being white have become a valuable asset that whites sought to protect and that those who passed sought to attain - by fraud if necessary. Whites have come to expect and rely on these benefits, and

\footnotetext{
${ }^{4}$ Many thanks to John Paul Jones for this insight.
} 
over time, these expectations have been affirmed, legitimated, and protected by law $(1993,1713)$.

This "pay off" can take the form of higher property values, better schools, or the ability to exclude people of color from the workplace. That whites feel they have the right to exclude others attests to the degree to which they assume ownership of this nation's opportunities ${ }^{5}$. The privileged position of whites is visible in almost every arena, including health, wealth, housing, educational attainment, and environmental quality ${ }^{6}$.

White privilege is particularly useful in the study of urban landscapes because it is simultaneously historical and spatial. Attempts to understand contemporary racial inequality in light of white privilege must be rooted in the past, precisely because of the absence of a hostile motive or single act. Since landscapes are artifacts of past and present racisms, they embody generations of sociospatial relations, what might be called the "sedimentation of racial inequality" (Oliver and Shapiro, 1995, 5). Similarly, white privilege, as a form of racism, is spatially expressed, indeed it is partially contingent upon a particular set of spatial arrangements. Take the case of neighborhoods. The full exploitation of white privilege requires the production of places with a very high proportion of white people. "Too many" people of color might reduce a neighborhood's status, property value, or general level of comfort for white people.

A brief example may demonstrate how white privilege allows us to historicize environmental racism: A polluter locates near a black neighborhood because the land is relatively inexpensive and adjacent to an industrial zone. This is not a malicious, racially motivated, discriminatory act. Instead, many would argue that it is economically rational. Yet it is racist in that it is made possible by the existence of a racial hierarchy, reproduces racial inequality, and undermines the well-being of that community. Moreover, the value of black land cannot be understood outside of the relative value of white land, which is a historical product. White land is more valuable by virtue of its whiteness (Oliver and Shapiro, 1995, 147-61), and thus it is not as economically feasible for the polluter. Nor is it likely that the black community's proximity to the industrial zone is a chance occurrence. Given the Federal government's role in creating suburbia, whites' opposition to integration, and the fact

${ }^{5}$ An oft-cited example of this is Senator Jesse Helm's 1992 campaign TV ad featuring a white working-class man denied a job, what should have been his job, because of affirmative action (Omi and Winant, 1994, 182).

${ }^{6}$ This is not to deny the vast differences within the categories of "white" and "people of color." Whites are obviously fragmented by class, gender, sexuality, and ethnicity (Brodkin, 1998). Likewise, various nonwhite groups are differentially racialized. For instance, although Asian Americans have the highest incomes of all people of color, they also are frequent targets of hate crimes. The point is that "the color line" remains a central axis of difference and inequality. 
that black communities have been restricted to areas whites deemed undesirable, can current patterns of environmental racism be understood outside a racist urban history?

The final issue of white privilege is, at whose expense? It is impossible to privilege one group without disadvantaging another. White privilege comes at the expense of nonwhites. Historically speaking, suburbanization can be seen as a form of white privilege, as it allowed whites to live in inexpensive, clean, residential environments (Jackson, 1980). It was a privilege denied to most people of color, but one they also bore the cost of, both in terms of an erosion of central-city quality of life, and in their direct subsidization of white suburbia through their tax dollars (Guhathakurta and Wichert, 1998). White privilege is useful in discussing suburbanization and environmental racism because it shifts our understanding of racism beyond discrete siting acts, while also emphasizing the spatiality of racism.

\section{Racism and Space in Environmental Racism Research}

Currently, many methodological issues are being debated within the environmental justice literature (Cutter, 1995; see Been, 1995). Unfortunately, the nature of racism is not one of them. In a review of thirty recent empirical studies, only a handful attempted any substantive discussion of racism itself (Baden and Coursey, 1997; Bullard, 1990; Hamilton, 1995; Krieg, 1995; Pulido et al., 1996; UCC, 1987)7, although others have probed the nature of race and racism in general (Bullard, 1994; Goldman, 1996; Pulido, 1996; Szasz and Meuser, 1997; Zimmerman, 1994). Instead, the literature is largely characterized by "common sense" assumptions that reflect uncritical, popular understandings of racism ${ }^{8}$. A similar pattern exists in terms of spatiality. While space has received considerable attention, spatiality, meaning the relationship between social space and society (Soja, 1989), has not. Instead, spatial discussions have centered on issues of distance, location, and scale, eschewing a more theoretical conception of space (see Cutter and Solecki, 1996, 395, for an exception). An appreciation of spatiality, however, encourages greater attention to race, as it is one of the key social forces shaping our cities (and the U.S. as a whole). In this section, I review how racism and space are expressed in the literature by showing how three

7 The following studies included no significant discussion or problematization of racism: Adeola, 1994; Anderton et al., 1994a, 1994b; Been, 1994; Boer et al., 1997; Boerner and Lambert, 1994; Bowen et al., 1995; Burke, 1993; Cutter, 1994; Cutter and Solecki, 1996; Cutter and Tiefenbacher, 1991; Hird, 1993; Hurley, 1988; Lester et al., 1994; Mohai and Bryant, 1992; Napton and Day, 1992; Perlin et al., 1995; Sadd et al., 1999; Scott et al., 1997; Szasz et al., 1993; U.S. GAO, 1995; Yandle and Burton, 1996; Zimmerman, 1993. But Pollock and Vittas (1995), in a useful discussion, reconsider their findings in light of alternative conceptions of racism.

${ }^{8}$ This does not imply that the researchers themselves are not familiar with social scientific understandings of race, but only that these ideas have not found their way into the literature. 
practices contribute to an overly restrictive conception of racism and space. First, I discuss the emphasis on facility siting, second, the role of intentionality, and, third, spatial scale. I will address the first two together, as they are closely related.

\section{Siting and Intentionality in Discrete Acts of Racism}

Although an earlier generation of scholars explored the relationship between demographics and pollution (Berry et al., 1977), it was not until the 1980s that these issues were framed as environmental justice (McGurty, 1995; see Szasz and Meuser, 1997 for a complete review). The initial literature on environmental racism documented discriminatory outcomes (Bullard 1990; UCC 1987; U.S. GAO 1984), but did not delve into the processes producing them. Drawing on traditional social science understandings of racism, Bullard (1996) argued that discriminatory outcomes were evidence of racism, regardless of the mechanism (siting, housing discrimination, job blackmail), precisely because of the racist nature of the economy and the larger social formation. He defines environmental racism as "any policy, practice, or directive that differentially affects or disadvantages (whether intended or unintended) individuals, groups, or communities based on race or color" $(1996,497)$. Subsequent scholarship, however, has not only challenged the existence of environmental racism $^{9}$, but has produced an overly restrictive conception of racism. As a result, siting, as a discrete and conscious act, is often analyzed solely with respect to the locations of racially subordinated groups (Bullard, 1996, 493) without sufficient attention to the larger sociospatial processes that produced such patterns. Likewise, interpretations of environmental racism are considered suspect without "proof" of intentionality.

Historical studies are a good example of how this shift towards a more restrictive conception of racism has occurred. In addition to enhancing our understanding of environmental inequities (Baden and Coursey, 1997; Been, 1994; Krieg, 1995; Pulido et al., 1996; Yandle and Burton, 1996) ${ }^{10}$, historical research has also problematized racism by asking, what if the people came first? While potentially a fruitful line of inquiry, the narrow conception of racism informing the literature has resulted in challenges to claims of racism: What were the intentions of the responsible parties? For some scholars, if people subsequently moved to polluted locales, and if the motive is unknown, claims of racism, cannot be substantiated:

${ }^{9}$ In most cases, scholars simply want to establish if such inequities exist, but there has also been a move on the part of both corporations and politically conservative institutions to refute such claims (Anderton et al., 1994a, 1994b; Boerner and Lambert, 1994; see Goldman, 1996). I too, of course, am an ideologically committed scholar, one who would like to reframe the debate from an antiracist perspective.

${ }^{10}$ I do not include Hurley's seminal study of Gary, Indiana in this grouping because it appeared at roughly the same time (1988) as the UCC report (1987). Clearly, he was ahead of his time. 
which came first? Were the LULUs \{locally undesirable land uses\} or sources of environmental threats sited in communities because they were poor, contained people of color and/or politically weak? Or, were the LULUs originally placed in communities with little reference to race or economic status, and over time, the racial composition of the area changed as a result of white flight, depressed housing prices, and a host of other social ills? (Cutter, 1995, 117)

This quote summarizes an oft-stated sequence of events and conception of the problem. I do not dispute its accuracy, but rather its underlying conception of racism, and the absence within the larger literature of alternative explanations. This scenario is predicated on understanding racism as a discrete and hostile act. In effect, the siting of environmental hazards becomes the expression of a potentially racist act. Were polluters or the state consciously targeting nonwhite neighborhoods? Geographers have, understandably, preferred to address a more narrow set of concerns, rather than the more fundamental issues of environmental degradation (Heiman, 1990) or racism (Goldman, 1996; Pulido, 1996):

An issue as controversial as environmental equity requires research that assesses the spatial coincidence between environmental disamenities and minority or disadvantaged populations, prior to an analysis of causation and the role of racial intent (Bowen et al., 1995, 655).

While a laudable position, the resulting research agenda remains theoretically weak and offers only a limited understanding of how racism, environmental quality, and urban processes intersect. The following quotes illustrate not only the emphasis on siting, but also the extent to which siting and the motive accompanying it, versus outcomes, are key to ascertaining if racism exists.

Clearly, discriminatory siting is not the primary culprit behind these cases of "environmental racism." Instead, Houston's disproportionate distribution of landfills can properly be attributed to the dynamics of the housing market (Boerner and Lambert, 1994, 16, emphasis added).

There is, therefore, significant evidence of disproportionate siting. The evidence is flawed, however, in several respects. First, the evidence does not establish that the siting process, rather than market forces such as residential mobility, caused the disparity. ... Second, the evidence does not establish that siting decisions intentionally discriminated against people of color or the poor (Been, 1993, 1014, emphasis added).

A reasonable distinction is that between injustice in outcome and injustice in intent. Injustice in outcome is what most research has investigated, it can be ascertained by examining a point in time and seeing if minorities or the poor are disproportionately represented in areas where waste is. Injustice in intent concerns siting decisions that 
are racist in intent - the actual disproportionate siting of waste in poor, minority communities (Baden and Coursey, 1997, 4, emphasis added).

There are two points that emerge from these authors' attempts to analytically sever racism from larger social processes (such as housing markets): First, they exhibit the tendency to limit racism to siting, and second, they impose the requirement of intentionality.

Siting The emphasis on siting is significant for two reasons. First, it reproduces an erroneous understanding of urban dynamics as it separates larger sociospatial processes from explanations of environmental inequity. Second, it is, unfortunately, the primary mechanism considered in terms of discrimination. This can be seen, for instance, in the way that discriminatory siting is carefully distinguished from market forces, which supposedly are nonracist. Baden and Coursey (1997) go even further by making explicit which historical scenarios are potentially racist and which are not (Table 1). They offer six scenarios to explain a community's proximity to dangerous sites. Only scenarios 4 and 6, however, suggest a clear judgment of environmental racism $(1997,14)$. The authors make clear that siting is the only mechanism that can be equated with environmental racism. In referring to scenarios 1, 2, and 3, they note, "if people move into an area known to be dangerous they may be able to claim racism in lending or economic inequality, but the charge of discriminatory waste siting is tenuous" $(1997,14)$. This is not untrue, but it is highly problematic and illustrative of a limited understanding of racism and space. Neither the narrow conception of racism, nor the fetishizing of siting helps us understand the nature of environmental racism in an urban context. In particular, it does not recognize that space is essential to the (re)production of a particular racial formation, nor does it acknowledge the fundamental relationships between racism and the production of industrial zones, pollution, and residential areas (Arnold, 1998).

Table 1. Baden and Coursey's Six Sequential Scenarios and Conclusions

\begin{tabular}{|c|c|c|c|c|}
\hline \multirow[b]{2}{*}{ Scenario } & \multicolumn{3}{|c|}{ Event } & \multirow[b]{2}{*}{ Description } \\
\hline & 1 & 2 & 3 & \\
\hline 1 & Siting & Danger & People & People move into an area known to be dangerous. \\
\hline 2 & Siting & People & Danger & $\begin{array}{l}\text { People move into an area which is later determined to } \\
\text { be dangerous. }\end{array}$ \\
\hline 3 & Danger & Siting & People & $\begin{array}{l}\text { A dangerous facility is sited, then people move into } \\
\text { the area. }\end{array}$ \\
\hline 4 & Danger & People & Siting & $\begin{array}{l}\text { People live in an area, then a facility known to be } \\
\text { dangerous is sited near them. }\end{array}$ \\
\hline 5 & People & Siting & Danger & $\begin{array}{l}\text { A facility that is not known to be dangerous is sited in } \\
\text { a region where people live and is later determined } \\
\text { to be dangerous. }\end{array}$ \\
\hline 6 & People & Danger & Siting & A dangerous facility is sited in a community. \\
\hline
\end{tabular}

Source: Baden and Coursey (1997:14). 
Intentionality In the quote by Been, above, the author has clearly found evidence of disproportionate siting. Yet without using the word "racism," she contextualizes her findings so that the reader is alerted that charges of racism cannot be fully substantiated. She does so, first, by suggesting that market dynamics have not been considered, and second, by referring to the question of intentionality. Nor, she writes, does the evidence "establish that siting decisions intentionally discriminated against people of color." In effect, intentionality becomes the litmus test as to whether or not a racist act has been committed. Intentionality not only underlies discussions of racism, but also serves several purposes in defining it, as critical scholars of legal racism have pointed out (Armour, 1997; Crenshaw et al., 1995; Delgado, 1995). First, the requirement of intentionality reduces the likelihood of viewing collective actions as racist, as it is more difficult to prove group, rather than individual, intent. Second, the emphasis on intentionality allows for a continual contraction in the definition of racism, as seen in recent court rulings (Washington $v$. Davis). Finally, by the requirement of malicious intent, entire dimensions of the social arena are exonerated from contributing to racial inequality, including the unconscious (Devine, 1989; Lawrence, 1987). The normal functioning of the state and capitalism are thus naturalized, as racism is reduced to an aberration ${ }^{11}$.

A good example of limiting the domain of racism can be seen in conceptions of the market. Instead of viewing the market as both constituted by racism and an active force in (re)producing racism, scholars have treated it as somehow operating outside the bounds of race (for a fuller discussion, see Mohai and Bryant, 1992; Pulido, 1996, 146-47). This is troubling, given the extent to which discrimination and racism have been proven in the "free market," including in employment (Kirschenman and Neckerman, 1991), banking (Dymski and Veitch, 1996), and housing (Holloway, 1988). Do not these various forces shape a city, and influence where pollution will be concentrated? Such a limited conception of racism prevents us from either grasping the power and spatiality of racism or identifying its underlying effectivity in perpetuating environmental injustice.

\section{Scale and Racism}

In addition to siting and intent, spatial scale is also implicated in producing a narrow conception of racism, as it too reflects normative understandings of race and space. Scale is a major methodological issue in the environmental-racism literature (Bowen et al., 1995; Cutter, 1995; Perlin et al., 1995; Zimmerman, 1993). Not only have researchers examined environmental inequity at different scales, but the question

${ }^{11}$ The notion of racism as an aberration, or as an irrationality is an entrenched part of the liberal discourse on racism. For a critique, see Crenshaw et al. (1995). On the history of racism, see Goldberg (1993). 
of what is the most appropriate scale has also been contested. Evidence suggests that different units of analysis, such as counties, zip codes, or census tracts, may produce different findings. For instance, county-level data may reveal a pattern of environmental racism, but a census-tract analysis of the same area may not (Bowen et al., 1995; Anderton et al., 1994a). Zimmerman illustrates how spatial scale may confound attempts to "prove" racism.

How boundaries can affect the outcome of an equity analysis in the judicial context was underscored in the East Bibb case. ... The court used a census tract to define the boundary around an existing landfill, and, on that basis, ruled that a predominantly white community surrounded the landfill; plaintiffs, in contrast, argued that a larger area encompassing both the existing site and a proposed waste site was predominantly black (70\%). Another case, Bean v. Southwestern Waste Management Corporation, employed statistical analyses both city-wide and for an area more proximate to a solid waste facility (defined at the census tract level) ... The court, using statistical findings at both geographic levels, ruled that even though no discrimination existed at the tract level, smaller neighborhoods within tracts where the facilities were located are important considerations in determining patterns of discrimination $(1993,652-53)^{12}$.

This quote not only demonstrates the problems associated with treating racism as an either/or phenomenon, but also suggests the extent to which a limited understanding of scale is tied to a narrow conception of racism. Both are conceived as discrete objects, rather than as social processes. I do not mean to suggest that courts should not rely on such findings, or that discrete acts of racism are not important, but as geographers, one of our tasks should be to explain patterns and processes. This requires that we critically interrogate our concepts and tools. In this case, not only must we acknowledge structural racism and reconceptualize it as a power relation, but we also need to contextualize scale. As Neil Smith has argued, we need to recognize scale as socially produced, rather than to treat it as a "methodological preference for the researcher" $(1993,96)$. Besides appreciating the fuzzy edges of spatial units, we must recognize that places are the products of a specific set of social relations (Massey, 1994; Soja, 1989). Moreover, the relevant social relations do not reside solely within the spatial unit under consideration. Rather, places are produced by other places, what Massey (1994) calls "stretched out" social relations. Thus, not only must our analysis operate at several scales simultaneously, but we must also consider the functional role

12 The cases cited are East Bibb Twigs Neighborhood Association v. Macon-Bibb County Planning and Zoning Commission. 888 F. 2d 1573 (11th Cir.), affirmed 896 F. 2d (11th Cir. 1989), and Bean v. Southwestern Waste Management Corporation, 482 F. Supp. 673 S.D. Tex. 1979. In Bean, local residents felt that the siting decision was discriminatory but lost because they could not prove discriminatory purpose under Washington v. Davis. 
of those places and their interconnections. This has implications for how we use scale in studies of racism. We must bear in mind that our selected scale of analysis may not necessarily coincide with the scale of racist activity. If racism is constitutive of the urban landscape and various types of racisms operate simultaneously, then great care must be taken in our treatment of scale. Racism and its consequences do not necessarily cease at the edges of census tracts or city boundaries.

Accordingly, instead of treating spatial units as if they exist in a vacuum, the study of industrial pollution requires that our focus not be limited to the individual facility, but rather should address the larger industrial zone in which it is located (Arnold, 1998). In turn, the industrial zone must be understood in relation to workingclass suburbs, affluent suburbs, "inner cities,"13 and downtown areas. All of these places represent specific class relations that are functionally linked. At the same time, all these places are racialized, and racism works in particular ways in their formation and evolution.

Collectively, these three practices, the emphasis on siting, intentionality, and a static conception of scale, have a limited ability to explain the geography of urban environmental hazards, particularly their concentration in industrial zones (Anderton et al., 1994b; Baden and Coursey, 1997; Cutter and Tiefenbacher, 1991; Sadd et al., 1999; Pulido et al., 1996). Anderton et al. (1994b, 239), in their national study of transfer, storage, and disposal facilities (TSDFs), found "the clearest and most consistent finding across the country is the apparent association between the location of TSDFs and other industrial enterprises" ${ }^{\prime 14}$. This finding suggests the need to clarify the relationship between industrial zones, suburbanization, inner cities, and race. As Been has suggested,

Many factories and other sources of hazardous waste were traditionally located in the center city because of greater access to transportation and markets. In some cities, developers provided cheap housing for workers in the surrounding areas. As workers moved away, either because factories closed or because more desirable housing became affordable elsewhere, the cheap housing in the center cities became disproportionately populated by the poor and by people of color (Been, 1993, 1017, emphasis added).

${ }^{13}$ I place the term "inner city" in quotes to denote both the fact that it is socially constructed and problematic as a policy and social science concept.

${ }^{14}$ The work of Anderton et al. (1994a and b) has been widely criticized on several grounds. The authors' finding of no environmental racism has been challenged on methodological grounds (Been, 1995), as has their participation in industry-supported research (Goldman, 1996, 132-34). Nonetheless, their [views] on industrial land use has increasingly been corroborated. 
This process of how "workers moved away" is one key to understanding contemporary patterns of environmental racism. It is my task to unpack this process.

\section{Environmental Racism, Urban Space, and White Privilege in Southern California ${ }^{15}$}

\section{Environmental Racism in Los Angeles County}

There have been six systematic studies of environmental racism in Los Angeles (five at the county level and one at the city), examining three environmental hazards: uncontrolled toxic waste sites (UCC, 1987), TSDFs (Sadd et al., 1999), and air toxins based on the Toxic Release Inventory (TRI) (Boer et al., 1997; Burke, 1993; Pulido et al., 1996; Szasz et al., 1993). Table 2 summarizes these studies. All studies found that nonwhites were disproportionately exposed. Most vulnerable were working-class Latinos $^{16}$.

The fact that three different hazards have been examined sheds light on distinct aspects of the urban environment. For instance, uncontrolled waste sites are often abandoned sites, thereby illuminating past industrial activities (Colten, 1986; Krieg, 1995; Newton, 1998). TRI data, which lists facilities emitting at least 10,000 pounds of air toxins annually, reflects largely contemporary industrial activities. TSDFs, despite their relatively small number, receive an inordinate amount of attention because they are high-profile projects requiring extensive permitting. In cities, they are often located in industrial zones because of their hazardous nature, as well as their proximity to waste generators.

The first study to suggest that environmental racism existed in Los Angeles was the United Church of Christ (UCC, 1987) report. Although national in scope, it examined the distribution of uncontrolled hazardous-waste sites in major cities, including Los Angeles, and found that Latinos were disproportionately exposed. In Figure 2, I have reproduced the original UCC map showing the concentration of waste sites in the eastern part of the city. Out of 57 waste sites, 35 (61.4 percent) were located in zip codes that were at least 50-percent Latino (UCC, 1987, 38) ${ }^{17}$. This area is not only one of the older industrial zones but also a longstanding Chicano barrio

${ }^{15}$ For this study, southern California is limited to Los Angeles and Orange Counties.

${ }^{16}$ Mexicano refers to persons of Mexican origin, mostly Mexican immigrants; Chicanos to persons of Mexican ancestry born in the U.S.; and Latinos, all Latin Americans.

17 Although the UCC study was based on 1980 census data and is therefore somewhat dated, this part of the city has only become more Latino during the 1980s and 1990s. Latinos now constitute upward of 90 percent of the population in this area (see Allen and Turner, 1997). 
Table 2. Summary of Six Studies Examining Environmental Hazards in Los Angeles

\begin{tabular}{|c|c|c|c|c|}
\hline Author/Year & Hazard & Unit of Analysis & Analytic Methods & Findings \\
\hline $\begin{array}{l}\text { United Church } \\
\text { of Christ } \\
(1987)^{\mathrm{a}}\end{array}$ & $\begin{array}{l}\text { Abandoned toxic } \\
\text { waste sites }\end{array}$ & $\begin{array}{l}\text { City of LA (except } \\
\text { harbor connector) } \\
\text { Zip codes }\end{array}$ & Descriptive analysis & $\begin{array}{l}\text { Latinos disproportionately } \\
\text { impacted }\end{array}$ \\
\hline Burke (1993) & $\begin{array}{l}\text { Facilities emitting } \\
\text { air toxins (TRI) }\end{array}$ & $\begin{array}{l}\text { Urbanized Los Angeles } \\
\text { County census tracts }\end{array}$ & $\begin{array}{l}\text { Bivariate mapping, } \\
\text { generalized linear } \\
\text { modeling, logit } \\
\text { analysis }\end{array}$ & $\begin{array}{l}\text { Latinos disproportionately } \\
\text { impacted }\end{array}$ \\
\hline $\begin{array}{l}\text { Szasz et al. } \\
\text { (1993) }\end{array}$ & $\begin{array}{l}\text { Facilities emitting } \\
\text { air toxins (TRI) }\end{array}$ & $\begin{array}{l}\text { Los Angeles County } \\
\text { census tracts }\end{array}$ & $\begin{array}{l}\text { Difference of means, } \\
\text { regression analysis, } \\
\text { comparison of } \\
\text { means, two-way } \\
\text { aggression analysis }\end{array}$ & $\begin{array}{l}\text { Black and Latino } \\
\text { households earning } \\
\$ 20-40,000 \\
\text { disproportionately } \\
\text { impacted }\end{array}$ \\
\hline $\begin{array}{l}\text { Pulido et al. } \\
\text { (1996) }\end{array}$ & $\begin{array}{l}\text { Air toxin emission } \\
\text { clusters (TRI) }\end{array}$ & $\begin{array}{l}\text { Urbanized Los Angeles } \\
\text { County census tracts }\end{array}$ & $\begin{array}{l}\text { Descriptive and } \\
\text { historical analyses }\end{array}$ & $\begin{array}{l}\text { Latinos disproportionately } \\
\text { impacted }\end{array}$ \\
\hline $\begin{array}{l}\text { Boer et al. } \\
\quad(1997)\end{array}$ & $\begin{array}{l}\text { Transfer, storage } \\
\text { and disposal } \\
\text { facilities } \\
\text { (TSDFs) }\end{array}$ & $\begin{array}{l}\text { Los Angeles County } \\
\text { census tracts }\end{array}$ & $\begin{array}{l}\text { Visual analysis, } \\
\text { univariate and } \\
\text { multivariate } \\
\text { analyses }\end{array}$ & $\begin{array}{l}\text { Working-class blacks and } \\
\text { Latinos disproportion- } \\
\text { ately impacted }\end{array}$ \\
\hline $\begin{array}{l}\text { Sadd et al. } \\
\qquad(1999)\end{array}$ & $\begin{array}{l}\text { Air toxins (TRI) } \\
\text { (facilities, size } \\
\text { of emissions, } \\
\text { relative } \\
\text { toxicity) }\end{array}$ & $\begin{array}{l}\text { Six southern CA } \\
\text { counties (Los } \\
\text { Angeles, Orange, } \\
\text { Ventura, Riverside, } \\
\text { San Bernadino, and } \\
\text { Imperial) census } \\
\text { tracts }\end{array}$ & $\begin{array}{l}\text { Univariate } \\
\text { comparisons, } \\
\text { binomial logit, } \\
\text { ordered logit, tobit } \\
\text { regression analysis }\end{array}$ & $\begin{array}{l}\text { Blacks and Latinos in } \\
\text { urbanized, central } \\
\text { Los Angeles } \\
\text { disproportionately } \\
\text { impacted }\end{array}$ \\
\hline
\end{tabular}

a The primary UCC study examined the relationship between commercial hazardous-waste facilities and community demographics. The study of abandoned hazardous wastes was a smaller component of the larger project and was less methodologically rigorous.

(Pulido et al., 1996; Romo, 1983; Sanchez, 1993). The area is legendary for its foulsmelling air, and includes one of the most polluted zip codes in the state (Kay, 1994).

The next group of studies examined facilities releasing air toxins (TRI). Figure 3 presents a map based on the data analyzed in the Sadd et al. (1999) study. ${ }^{18}$ This dataset contains by far the largest number of pollution events. Burke (1993) identified three key variables associated with census tracts containing TRI facilities: the high presence of minority populations (primarily Latinos), lower incomes, and highpopulation densities. The study by Sadd et al. $(1999,111)$ found that sites were concentrated in the "heavily urbanized metropolitan Los Angeles area ... in which the percentage of African American or Latino residents exceeds the mean for the study area". They, along with Szasz et al. (1993), also found that facilities were concentrated

${ }^{18}$ Many thanks to Jim Sadd and Environmental Data Resources, Inc. for allowing me to use this dataset. For both Figures 3 and 4, we took environmental hazards data from Sadd et al. (1999) and Boer et al. (1997) and overlaid it on 1990 census data. 
in working-class areas, rather than poor or wealthy ones (see also Cutter and Solecki, 1996). The study by Pulido et al. (1996) focused on emission clusters and found that the largest concentration of sites was located in the greater east Los Angeles and south Los Angeles areas ${ }^{19}$.

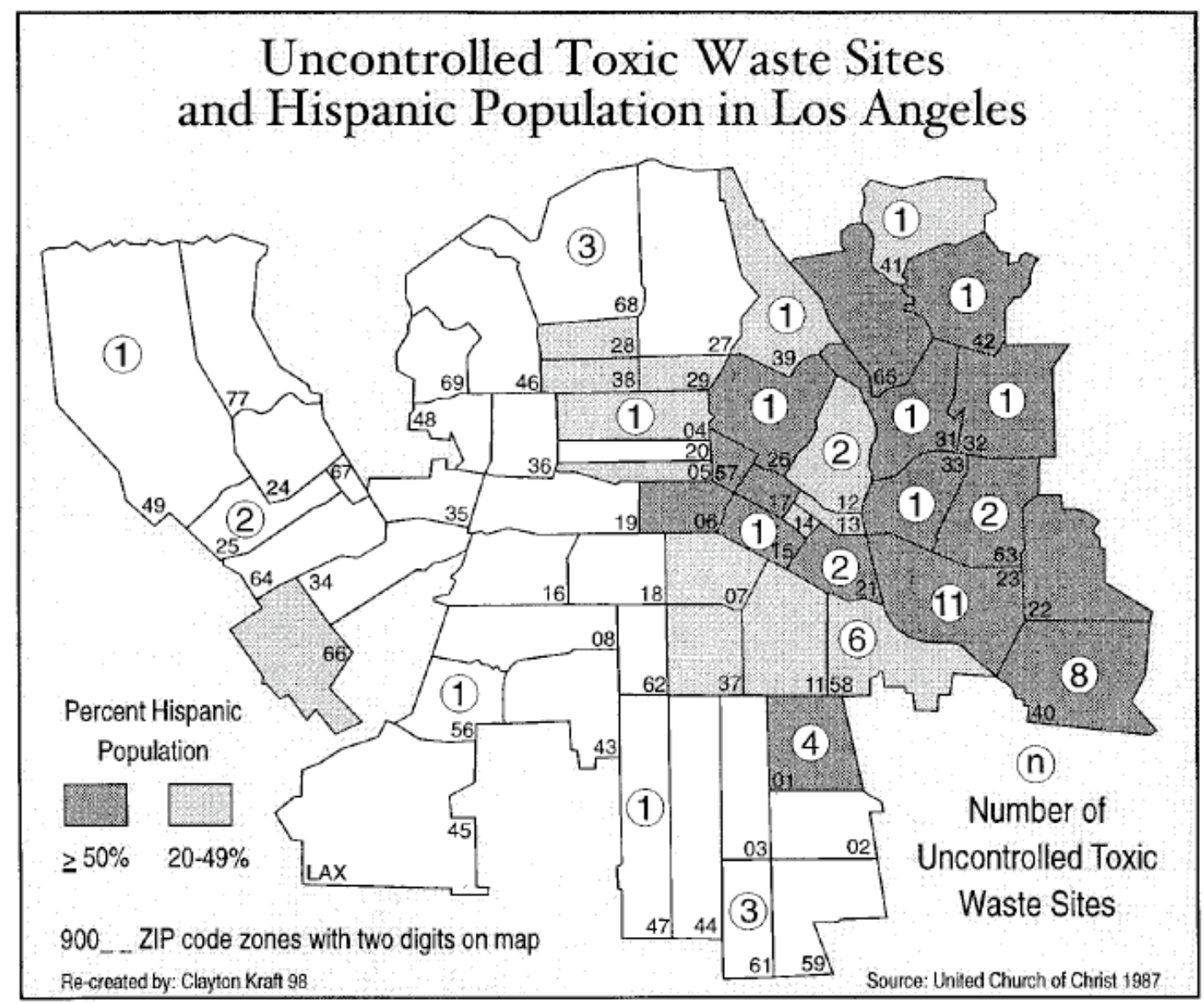

Figure 2. Southern California's first study of environmental racism: The United Church of Christ's study of uncontrolled hazardous wastes in Los Angeles city, 1987. The UCC study did not include the entire city - the "shoestring," or narrow corridor connecting the main part of the city with the harbor, is not shown.

${ }^{19}$ The single largest emitter was an oil refinery in Torrance, a mixed, middle-income city (see also Burke, 1993); at a more refined scale, however, it was found that the neighborhoods immediately adjacent to the refinery were primarily Latino. 
The final hazard studied is TSDFs. Figure 4 represents data analyzed by Boer et al. (1997). In this study, the authors found a pattern similar to Sadd et al. (1999) and Szasz et al. (1993): the disproportionate exposure of working-class communities of color. Using a multivariate model, the authors found that "race remains a factor along with industrial land use and employment in manufacturing; rising income, on the other hand, has a positive, then a negative effect on the probability of TSDF location" (1997, 795). They found that 5.2 percent of blacks and Latinos lived in a census tract containing a TSDF, but only 2.9 percent of whites did.

The results of these six studies suggest important racial and spatial patterns associated with these three forms of pollution. First, it appears that most industrial hazards in southern California are concentrated in the greater central and southern part of Los Angeles County. This older core is inhabited by people of color, while whites live on the periphery. Within this large zone, one group of hazards follows a major transportation corridor, the Interstate- 5 freeway and the railroad, stretching from east Los Angeles through downtown and into the eastern San Fernando Valley. A second major grouping forms a wide swath from downtown to the harbor. This distribution reflects both contemporary and historic industrial patterns. Second, as previously stated, all studies found evidence of environmental racism, even when accounting for income. This substantiates Perlin et al.'s (1995) finding that pollution is concentrated in a few large urban areas with substantial minority populations. Third, it is workingclass Latinos, and to a lesser extent, African Americans, who are disproportionately impacted. This reflects both patterns of residential segregation, as well as Latinos' historic and continuing role as the region's low-wage working class (Morales and Ong, 1993; Ong and Blumenberg, 1993; Scott, 1996a). What is significant is the degree to which almost no whites live in these areas and therefore are not exposed to the hazards under consideration ${ }^{20}$. As the maps in Figures 2-4 suggest, there is simply far less pollution in the outlying areas. I maintain that we can only understand these contemporary patterns by examining the historical development of urban space at the regional scale and that these processes are inherently racialized. While some forms of environmental racism are directly attributable to overt acts of discrimination, I will emphasize how white privilege contributed to this larger pattern.

${ }^{20}$ An important exception might be Superfund sites. Military production is responsible for serious ground and groundwater contamination, such as the Lockheed site in North Hollywood/Burbank, and Rocketdyne in the western San Fernando Valley. There has been no systematic study of this form of pollution throughout the region. 


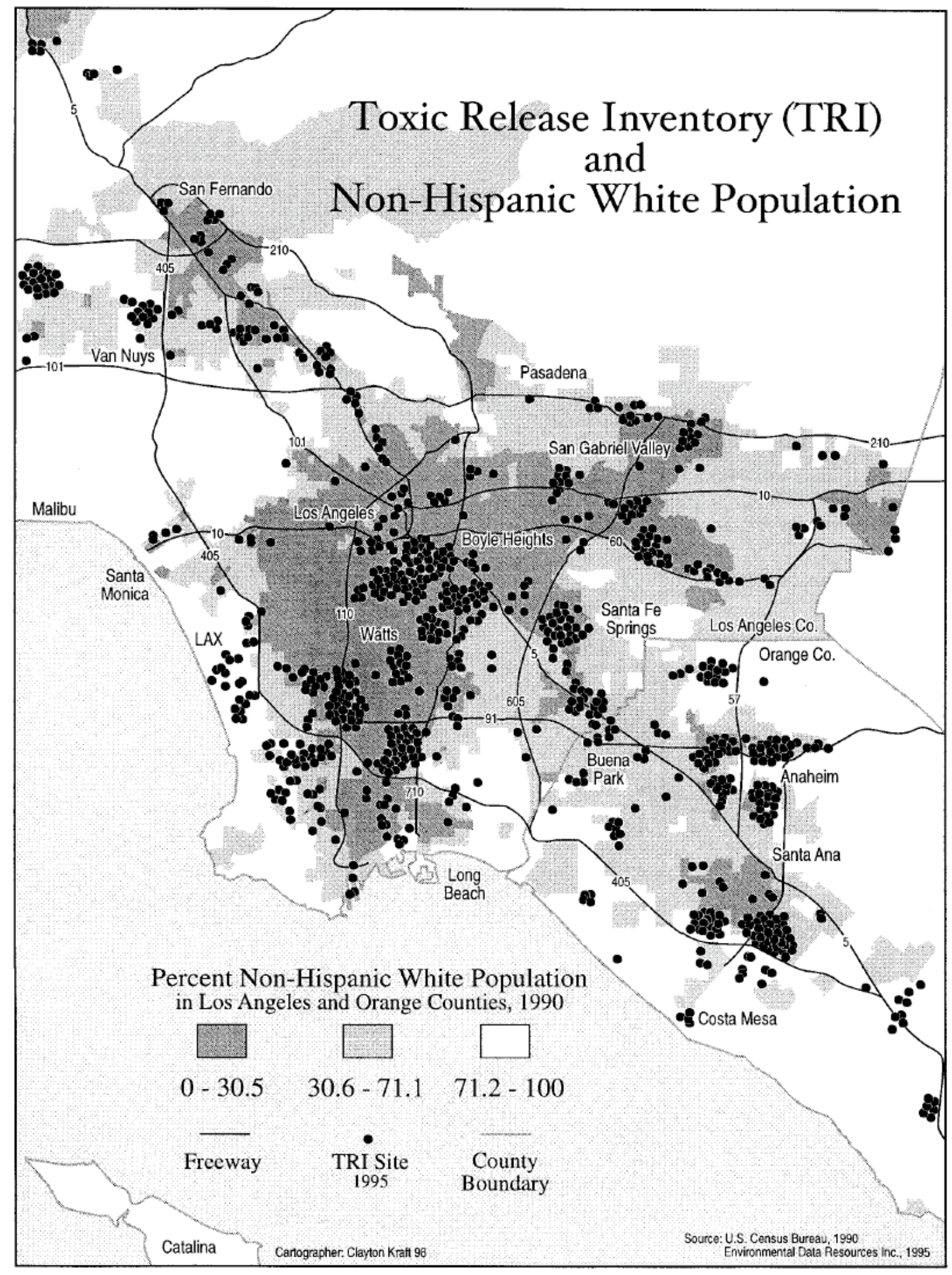

Figure 3. Distribution of Toxic Release Inventory (TRI) emission sites and non-Hispanic white population in Southern California. 


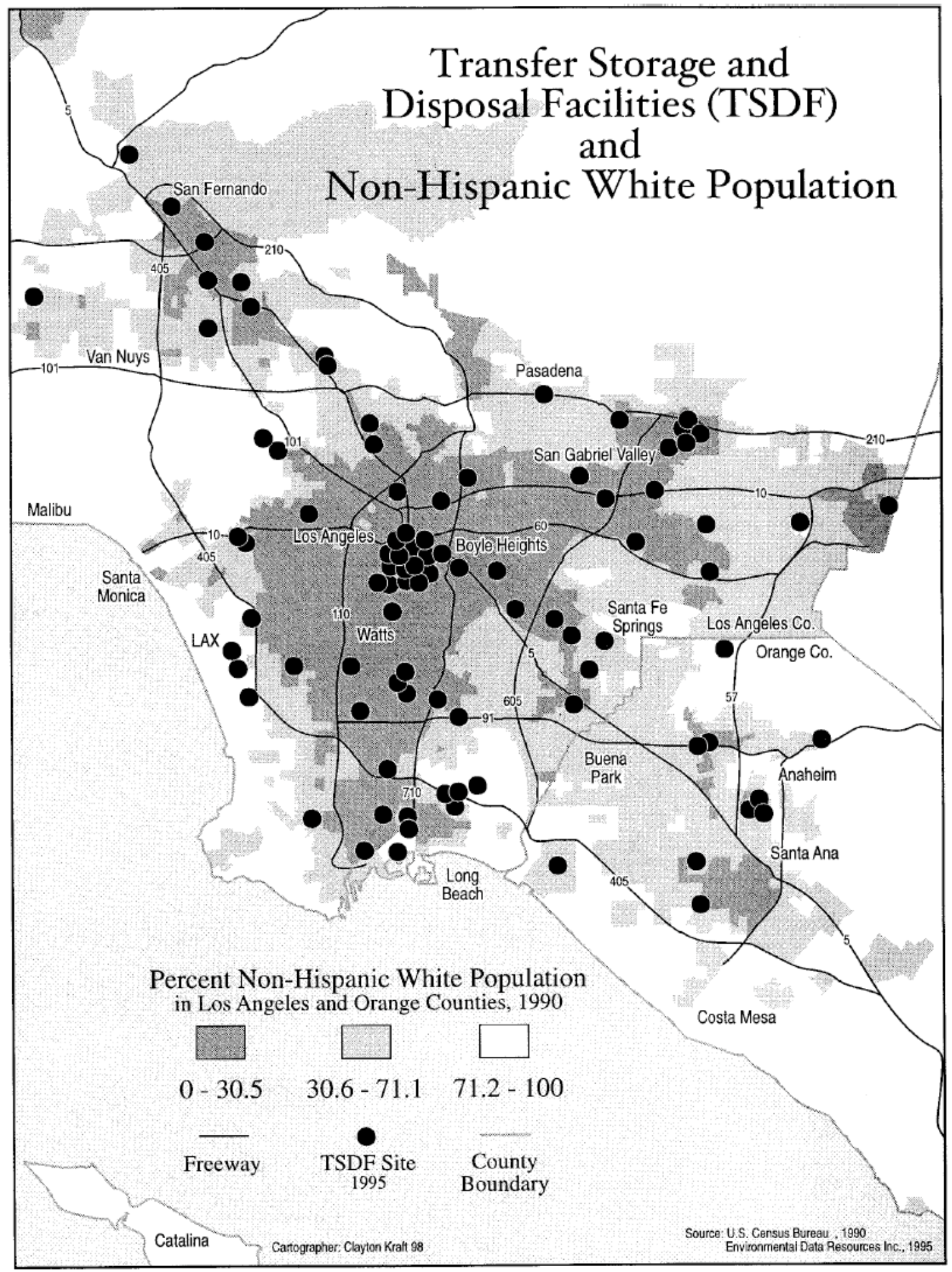

Figure 4. Distribution of Transfer, Storage, and Disposal Facilities (TSDF) and non-Hispanic white population in Southern California. 


\section{The Historical Geography of White Privilege and Environmental Racism in Los Angeles}

The data suggest that people of color's disproportionate exposure to pollution in Los Angeles is not by chance. Although the geography of environmental racism is the result of millions of individual choices, those choices reflect a particular racial formation, and are a response to conditions deliberately created by the state and capital (Harvey, 1985; Hise, 1998; Walker, 1981). My goal is to show the historical evolution of these patterns and how racism contributed to the spatial patterns associated with environmental racism.

Before offering this historical geography, however, it is useful to consider how Los Angeles is both similar to and unique from other urban areas. Although the nature and definition of suburbia is contested (Fishman, 1987; Garreau, 1991; Kling et al., 1995; Sharpe and Wallock, 1994), there is no denying that urban regions have undergone a fundamental restructuring over the last five decades, as whites and the middle class of all colors have moved outwards with significant consequences for inner cities. This process of deconcentration has been described as a "massive regional dispersal of population, industry, and commerce," entailing "the restructuring of both the central city and the outlying areas" (Gottdiener and Kephart, 1995, 33-34).

Los Angeles has not escaped these profound shifts, but its experience is also unique (Davis, 1992; Dear and Flusty, 1998; Soja, 1989, 1996). Unfortunately, the reality of Los Angeles is often obscured by the many misconceptions of the region (Soja, 1996, 427). For example, because of its legendary sprawl, many overlook the historical and contemporary significance of Los Angeles's inner cities. Though inner cities are often considered to be sites of poverty and pathos, this is too simple a reading. While both the eastside barrio and South Central are home to poor people of color, they are also sites of vibrant communities and an assortment of industry and warehousing. In addition, perhaps because of the influence of Hollywood and Disneyland, many do not realize that Los Angeles is the leading manufacturing county in the nation. Accordingly, the historical geography of industry has been a powerful force in shaping the region (Soja, 1989).

Suburbanization is also unique in Los Angeles, where, although not pioneered there, suburbia peaked, as real-estate speculation and "living the good life" became economic and social cornerstones of the region (Fishman, 1987, 155). Finally, while many U.S. cities have historically been characterized by bipolar racial structures (usually black/white), only recently have they become multiracial. In contrast, Los Angeles has always been racially diverse. This is important in that the long presence of various racial/ ethnic groups illustrates how nonwhites differentially experienced racism, underscoring the profundity of white privilege.

Early Residential and Industrial Patterns, 1848-1920s Early suburbanization emanated partly from the refusal of middle-class whites to live near immigrants and 
people of color. Whites pursued suburbanization for many reasons, but regardless of their motives, their choice was predicated on white privilege. Historian Robert Fogelson (1993) has pointed out that soon after the Anglo takeover of Los Angeles (1848), the city was transformed from a spatially clustered community to a rapidly expanding city. This transformation was driven by several forces, including a growing population, land speculation, and the fact that many newly arrived white Angelenos were native-born and refused to live near socially subordinated groups. Fogelson (1993) has argued that because the whites who came to Los Angeles were relatively secure financially, they were more concerned with lifestyle issues, rather than economic survival, and their affluence led them to embrace suburbia. Hence, whites' residential desires and real estate interests were two of the more powerful forces that shaped early Los Angeles:

the unique dispersal of Los Angeles reflected not so much its chronology, geography, or technology as the exceptional character of its population. It was not like Chicago ... inhabited largely by impoverished and insecure European immigrants, who ... were confined to the city's teeming tenements and crowded ghettos. ... Los Angeles was populated principally by native[-born] Americans with adequate resources and marketable skills, who faced the problems of adjustment confidently because of a common language and similar background. ... Moreover, the native[-born] Americans came to Los Angeles with a conception of the good community which was embodied in single-family houses, located on large lots, surrounded by landscaped lawns, and "isolated" from business activities. Not for them multi-family dwellings ... separated by cluttered streets and ... industry. Their vision was epitomized by the residential suburb (Fogelson, 1993, 144).

In addition to the exclusionary desires of white Angelenos, suburbanization was also promoted by industrialists who sought to provide housing for the white working class as a means of avoiding labor unrest. According to one promotional brochure,

The real secret of the efficiency of the workers of Southern California may be found in their home life. ... A tenement is unknown here and the workers live in their own little bungalows surrounded by plenty of land for fruits, vegetables and flowers, and where children romp and play throughout the entire year. ... This spells contentment and contentment spells efficiency (LA Chamber of Commerce Industrial Department, 1926).

As whites moved outward, Chicanos, African Americans, Japanese Americans, Chinese Americans and the remnant Indian population were relegated to San Pedro, Watts, and the central city (including downtown and the eastside) (Anderson, 1996, 342-46; Horne, 1995, 27; Romo, 1983; Sanchez 1993; Warren, 1986-1987). Beginning 
in the 1920s, residential segregation was violently enforced (De Graff, 1970; Massey and Denton, 1993). As a result, for thousands of

Mexicans, Japanese, and Negroes who lived amidst commerce and industry in the small ghettos of central Los Angeles and San Pedro\{,\} there were a million white Americans who resided in the suburbs sprawling north to Hollywood, east to Pasadena, south to Long Beach, and west to Santa Monica (Fogelson, 1993, 147).

These early differences in environmental quality were codified by zoning laws in the 1920s, which resulted in a concentration of industrial activity in nonwhite and immigrant areas (The Zoning Map Company, 1930).

This early process of white outmigration was characterized by various forms of racism. For one, the fact that nonwhites were considered undesirable reflects a racial hierarchy. More conscious was the exclusion of people of color from white housing developments. While most developers practiced overt discrimination by denying housing to people of color, they may have had distinct motives. Some may have opposed nonwhites living with whites, while others may simply have realized that the presence of nonwhites would reduce property values. Regardless of the motive, however, all these actions were predicated on white privilege and served to undermine the well-being of people of color. This is an example of how white privilege can coexist with other forms of racism in shaping residential patterns.

Until the 1920s, the industrial sector was weak and clustered downtown due to limited infrastructure. During the 1920s, however, civic leaders sought to build the region's manufacturing base in order to diversify the economy. Between 1919 and 1933, Los Angeles County rose from twenty-seventh to sixth in terms of the value of manufactured goods (LA Chamber of Commerce Industrial Department, 1934). Several factors guided this growth, including the success of the "branch plant" strategy, capital's desire to escape organized labor and zoning regulations (LA Chamber of Commerce, Industrial Department, 1929), and the coordinated efforts of industrialists, developers, and planners to transform the basis of Los Angeles's landscape from tourism and land speculation to manufacturing (Hise, 2000; Fogelson, 1993).

The resulting manufacturing and residential geographies have had an enduring influence. Mexicanos and industry were continually pushed eastwards from the central Plaza, towards the Los Angeles River (Romo, 1983; Sanchez ,1993), further cementing the barrio's role as an industrial district. Industrialists and planners chose to develop this site, given its proximity to the railroad, in hopes of generating cargo tonnage (Los Angeles Central Manufacturing District, 1923). Partly because of the existing industrial infrastructure (railroads, industrially zoned land, already-contaminated land), and the availability of a large pool of low-wage labor, the eastside remains an important industrial area. 
The production of urban space in Los Angeles in the 1920s shows how race and class influenced the location of both residential and industrial districts. Affluent whites moved to residential suburbs like Pasadena, Bel Aire, Rancho Palos Verdes, and Beverly Hills, and were never seriously threatened with industrial activity. Instead, industry developed in conjunction with nonwhite spaces (the eastside and south of downtown) and the white working class. As previously mentioned, industrialists' desire to avoid labor unions (concentrated downtown), and to placate white labor through home ownership, led to the development of industrial suburbs. The creation of communities like Torrance, Huntington Park, and Bell offered a suburban experience to all whites, regardless of class (Parson, 1984). The strength of the color line can be seen in the way Bell, for instance, boasted of providing "homes for industrial workers \{with\} no Negroes and very few Mexicans and Chinese" (LA Chamber of Commerce Industrial Department, 1925). Likewise, Compton described itself as having "inexpensive homes of individuality, where flowers and gardens may be grown the year round. White help prevails" (LA Chamber of Commerce Industrial Department, 1925). Yet, despite the overwhelming power of white privilege in (re)producing the color line, it is also evident that this articulation of racism is predicated not only on class divisions within the white population (which allowed for the creation of affluent communities), but also an attempt to incorporate those who were previously considered to be "not quite white" (Brodkin, 1998) into new forms of consolidated whiteness.

As suburbanization continued, what were once the near suburbs became the inner city, as white workers moved away, and people of color subsequently took their place, a process known as ethnic succession ${ }^{21}$. Consequently, wealthy whites were never systematically burdened by pollution, while over time, the white working class was able to escape by taking advantage of new housing opportunities. Thus, regardless of class differences, all whites enjoyed white privilege, albeit to varying degrees.

Residential and Industrial Expansion in the World War II Era The Depression and World War II greatly intensified the process of white suburbanization, but instead of it being a private project, the state actively subsidized suburbanization, to the detriment of people of color living in the central city (Ebner, 1987, 234-35; Guhathakurta and Wichert, 1998). Figure 5 shows the exodus set in motion by the policy and economic shifts of World War II. Not only did whites continue their outward migration, but millions of newly arrived white Angelenos settled in the suburbs. In contrast, newly arriving African Americans and Mexicanos were relegated respectively to the ghetto and barrio. And Japanese Americans, upon their postwar release from concentration camps, clustered in black and brown spaces, such as the

${ }^{21}$ This is an important issue that few have seriously addressed - the historic exposure of the white working class. The fact that working-class whites may have been disproportionately exposed in the past does not detract from the argument that environmental racism exists today. Rather, it suggests the changing nature of race, and the need to historicize its spatiality. 
Crenshaw area and Boyle Heights, as well as in rural communities like Gardena (Warren, 1986-1987).

The economic growth triggered by defense dollars not only provided jobs, but housing these workers created a construction boom. Hise has argued that this period is pivotal to explaining the contemporary fragmentation of southern California: "the emergence of Los Angeles as a fully urbanized region occurred around a set of decentralized industrial growth poles ... \{and the industrial and housing policy associated with the defense emergency accelerated this emergent pattern of decentralization" (1993, 97-98) (Figure 6).

Federal policies, such as Titles I and VI of the Federal Housing Act (FHA), sought to increase the housing supply (Doti and Schweikart, 1989), in an overtly racist way. Perhaps of greatest significance was the institutionalization of redlining practices by the Home Owners Loan Corporation (HOLC) and the FHA. Although these measures were intended to protect small homeowners from foreclosure, they ranked neighborhoods in descending order from " $A$ " to " $\mathrm{D}$," with profound consequences for future urban development. "A" ratings were reserved for "newer, affluent suburbs that were strung out along curvilinear streets well away from the problems of the city" (in Jackson, 1980, 424).

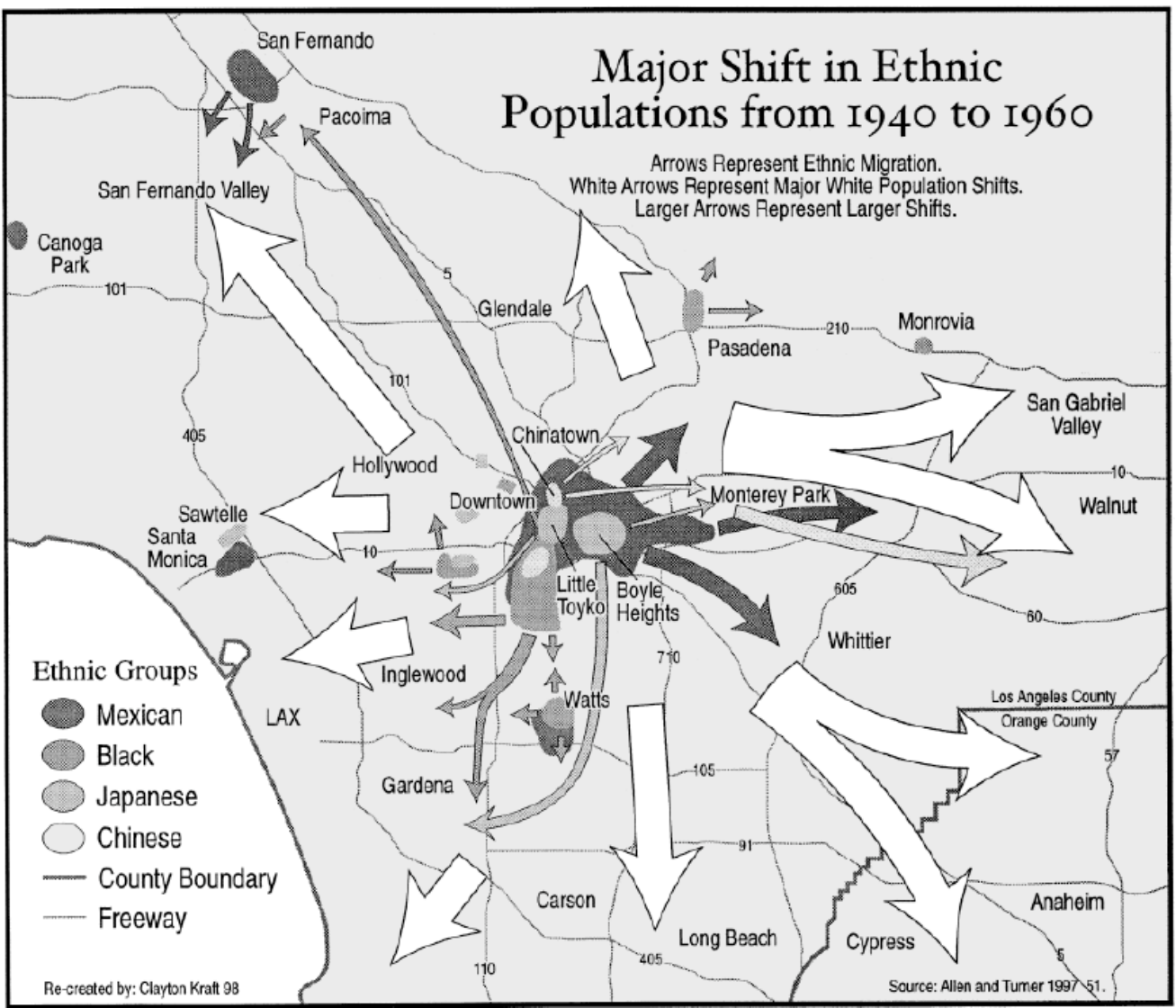


Figure 5. Racial/ethnic outmigration from central Los Angeles between 1940 and 1960.

At the other extreme were nonwhite neighborhoods. Indeed, HOLC's survey of the Los Angeles area shows the suburban communities of Pasadena, Beverly Hills, Santa Monica, and Palos Verdes as all "A" areas. Working-class white communities were "B," and Black, Latino, and Asian neighborhoods, primarily in the eastside, central Los

Angeles, and south of downtown, were "C" and "D" (U.S. Division of Research and Statistics, 1939). A confidential report by the survey team illustrates the degree to which black and brown people were considered a problem and a potential threat to white residential development:

Negroes do not constitute a racial problem in the area as a whole, for although they too have been increasing rapidly in number, their ratio to the total county population has remained constant since 1890 . The Negro race is fairly well confined to a few sections within the county. They occupy one large area southwest of the business district. ... Although Beverly Hills shows a larger than average number of Negroes, these are made up entirely of servants and they do not own property in the community. ... The major racial problem existing in Los Angeles, and one which is not revealed by the census data, is that created by the large numbers of Mexicans, who are classed as Whites by the Census Bureau. ... While many of the Mexican race are of high caliber and descended from the Spanish grandees who formerly owned all the territory in southern California, the large majority of Mexican people are a definite problem locally and their importation in the years gone by to work the agricultural crops has now been recognized as a mistake (Bowden and Mayborn, 1939, emphases added).

The results of such overt and institutionalized forms of racism were evident in dramatic urban inequalities. For instance, despite the outlawing of restrictive covenants in 1948 (which Californians subsequently repealed), less than two percent of the housing financed with federal mortgage insurance was made available to blacks (Anderson, 1996, 345). Moreover, in 1955, the ratio between single-family and multifamily starts was more than nine to one in Los Angeles (Cohan, 1956, 46). Because they were largely excluded from the new suburbs, the limited production of multifamily units meant greater crowding in the barrio and ghetto. Minority 
communities were also disadvantaged insofar as massive funds were channeled into suburbia $^{22}$.

Not only was less money available for inner-city development, but such projects were often built literally at the expense of nonwhites. For example, Los Angeles's freeway system, upon which the suburban structure was predicated, was largely built through communities of color, particularly Chicano neighborhoods, resulting in severe disruption to the community and its housing stock (Avila, 1998). The result of these practices was evident in growing racial and economic polarization. In 1960, the average income in central and east Los Angeles was \$5,916, while it was $\$ 8,575$ in the outlying, newly developing areas ("Los Angeles 1965: Market and Media", 1965, M12) ${ }^{23}$.

A related segregation tool was suburban city incorporation. The exclusionary nature of suburbanization is underscored by the fact that once people arrived, they sought to insulate their investment through incorporation. Not only did this protect their tax dollars, but it offered them more control over local land use, including industry, schools, and the ability to exclude outsiders, through, for example, restrictive covenants, advertising practices, and minimum lot-size standards (Babcock and Bosselman, 1973; Miller, 1981). Between 1955 and 1960, twenty-five communities incorporated in Los Angeles County (Miller, 1981, 22), resulting in a total of more than 76 incorporated cities ("Los Angeles 1965: Market and Media", 1965, M3)"24.

The issue of incorporation versus suburbanization demonstrates the multiple forms of racism shaping the region. For some, moving to suburbia might simply be taking advantage of opportunities based on one's white skin. While this opportunity is predicated on institutionalized racism, incorporation is potentially a more conscious and deliberate act to maintain one's privilege (often in the form of property values). In Torrance, for instance, an integration campaign led by the Congress on Racial Equality

22 This occurred through both a diversion of funds and a direct subsidy. For instance, the Bradly-Burns Act of 1956 authorized local municipalities in California to collect a one-cent sales tax for their own use. Because many urban residents shopped in new suburban malls, they in effect subsidized outlying areas, thereby allowing them to maintain low or nonexistent property taxes (Davis, 1992, 166).

${ }^{23}$ I reached these figures by averaging the reported incomes for the following communities as identified in the Los Angeles Times media market. For the inner city, I included the Northeast, East, Central, and Southeast. For the periphery, the San Fernando Valley, Glendale, South Coast, and Orange County ("Los Angeles 1965: Market and Media", 1965, 15, M12).

${ }^{24}$ An important impetus for this incorporation boom was the planned community of Lakewood, which pioneered a contract-based form of municipal government (Brill, 1996, 98). Many communities emulated this plan, what has been called the "Lakewoodization" of southern California (Davis, 1992, 166). 
(CORE), a civil rights group, was fiercely resisted by whites. White opposition ranged from parades featuring Nazis and the Klu Klux Klan, to white homeowners planting American flags and signs on their lawns saying "without property rights there are no human rights" (Weeks, 1963). While the reference to "property rights" may appear disingenuous, it is quite telling in that it reveals the necessity of preserving whiteness in order to protect one's investment and a particular quality of life.

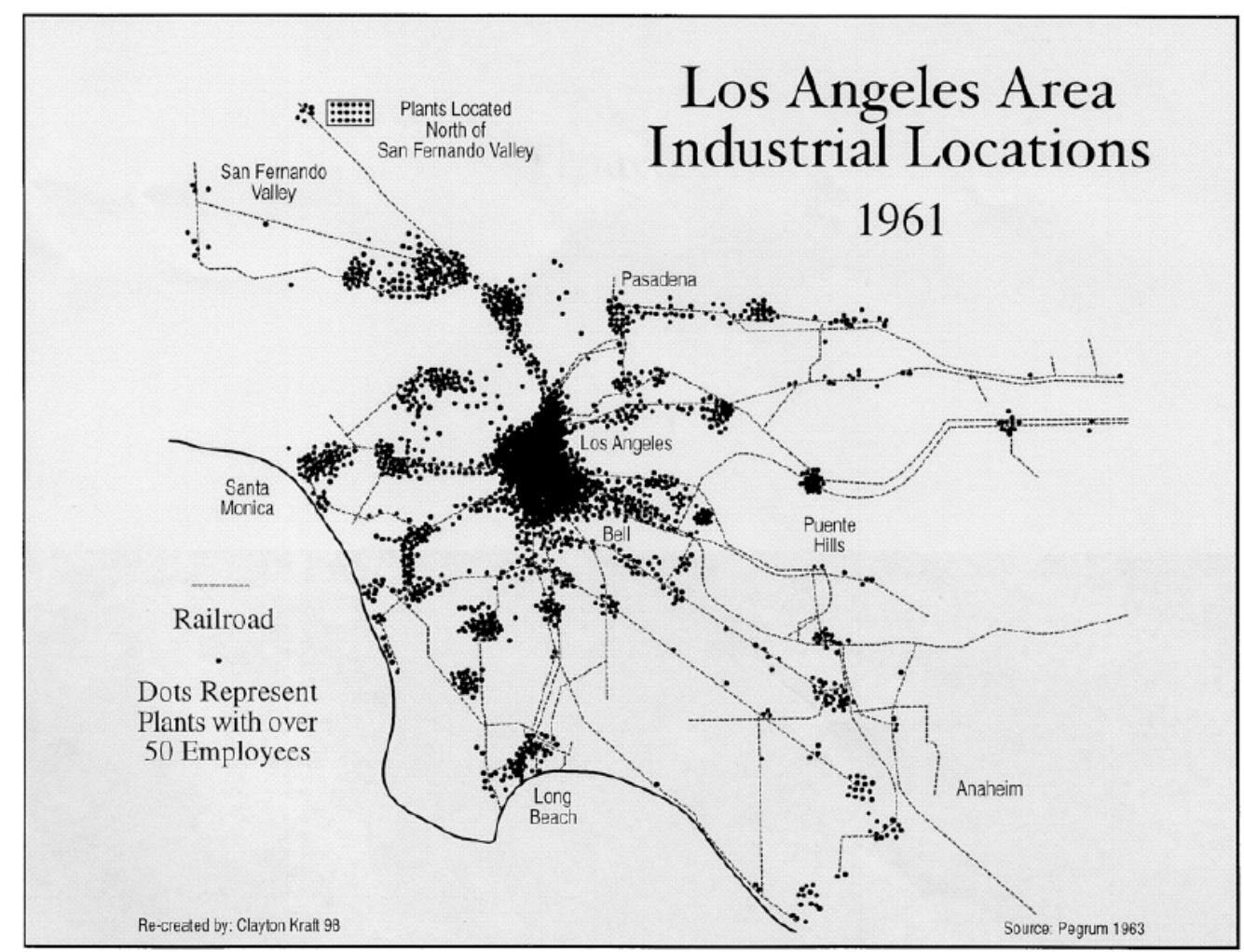

Figure 6. Distribution of industrial concentrations in Southern California, 1961.

What is significant is not that some whites refused to live among nonwhites, but the extent to which social status and a desired quality of life are predicated on homogeneous whiteness.

That suburbanites effectively wall out those unlike themselves after arriving \{in suburbia\}, however, suggests that a major force driving their migration is the wish to escape racial and class intermingling. In the United States, upward mobility and social status are predicated on living apart from racial and economic groups considered inferior. ... Thus, it is not simply the racism of individuals but also the collectively perceived threat that race and class differences pose to homeownership and social 
standing that drives suburbanites to keep their territory segregated (Sharp and Wallock 1994, 9, emphasis added).

The quote emphasizes the connection between individual actions and social structures. While some undoubtedly had malicious intentions, others did not. Yet, in order to preserve and fully exploit the privilege associated with whiteness, presumably wellintentioned individuals respond to market forces and social structures in ways that reinforce racist hierarchies.

This process highlights not only the spatiality of racism, but also the fact that space is a resource in the production of white privilege. Indeed, neighborhoods are not merely groupings of individuals, homes, and commerce, they are constellations of opportunities with powerful consequences, for both the recipient and nonrecipient populations. Although whites must go to ever greater lengths to achieve them, relatively homogeneous white spaces are necessary for the full exploitation of whiteness (Frankenberg, 1993).

Beginning in the 1950s, the urban exodus was driven by the relocation of key industries and government services. Led by Northrop, Hughes, and Lockheed, aerospace firms left central Los Angeles in a leapfrog pattern, creating industrial agglomerations (Lockheed Aircraft Corporation, 1953; Scott, 1996b). As a result, wellpaying defense jobs shifted to Los Angeles's periphery (Law et al., 1993), and racial and economic polarization became more entrenched. There was a strong relationship between the defense industry and white workers. White workers followed the industry, which moved to areas amenable to whites. For instance, a labor-market survey described Fullerton as undergoing a "significant expansion in industries related to the missile program" (California Department of Employment, 1960), and as having a labor force that was primarily "native-born white" (California Department of Employment, 1952).

Many factors contributed to this industrial and urban decentralization. Besides population growth, new production methods required larger lots, which were increasingly hard to find in Los Angeles. Indeed, 76 percent of Los Angeles's capital investment in 1955 was spent on existing businesses as they sought to expand (Banks, 1956, 63). In addition, there was a desire to escape congestion, and quality of life concerns greatly intensified after the Watts riots (1965). Consequently, new communities were built along Los Angeles's periphery, including the San Fernando Valley, the South Bay, and Orange County (Kling et al., 1993, 3; Scott, 1990, ch. 9). Between 1960 and 1965, Los Angeles

County experienced a population growth rate of 21.4 percent, while Orange County averaged 137.5 percent ("Los Angeles 1965: Market and Media", 1965, M14). Despite Orange County's exceptional growth, however, relatively few people of color moved there. While Los Angeles's population was 19.2 percent nonwhite in 1960, Orange County was only 8.8 percent nonwhite (LA Chamber of Commerce, 1964). 
Besides affordable housing and well-paying jobs, white Angelenos were lured to new, attractive, segregated communities, such as Irvine, the quintessential planned community. The developer, the Irvine Company, believed that both affordable and integrated housing would reduce property values and deter desirable buyers. One official explained that a multiracial advertisement, "would scare off every white person I had even the slightest hopes of getting" (Schiesl, 1995, 68).

Nonetheless, by the 1970s, a decrease in overt racism and a strong economy allowed people of color to enjoy more housing options. The San Gabriel Valley became the path of upward mobility for Chicanos, and Asian Americans became increasingly dispersed throughout the region. Eventually, the enforcement of civil rights laws enabled blacks to move beyond central and south Los Angeles.

Contemporary Patterns Due to 150 years of racism as well as recent social and economic shifts, southern California remains highly segregated, despite a reduction in overt forms of racism. Three interrelated factors help explain why the central city remains a nonwhite place, and whites continue to dominate the periphery: immigration, residential mobility, and economic restructuring. These factors also help explain why Latinos, in particular, are disproportionately exposed to industrial pollution.

Immigration has dramatically affected both the economy and residential patterns of the region. Between 1970 and 1990, the Asian population of Los Angeles increased by 451 percent (Cheng and Yang, 1996, 308), while between 1980-1990, the Latino population rose from two million to well over three million (Morrison and Lowry, 1994, 28). Although these new arrivals settled throughout the region, many clustered in east, central, and south Los Angeles. At the same time, African Americans, while still heavily concentrated in south Los Angeles, have been moving east to the "inland empire" and even returning to the South (Johnson and Roseman, 1990). Immigrants have moved into these black and brown spaces because they are affordable and accessible. Immigrants do not settle just anywhere, however. Their decisions are informed by the geography of past racial regimes. As a result, central Los Angeles continues to be a nonwhite space (Allen and Turner, 1997, 46). This growth is juxtaposed by the loss of 352,000 whites between 1980 and 1990 (Sabagh and Bozorgmehr, 1996, 86). Not only do whites continue to move to Orange County (especially popular are the southernmost communities where whites sometimes constitute up to 90 percent of the population), but the flight of white Angelenos has spread to San Diego, central California, and throughout the West (Frey and Liaw, 1998). Even white "holdout" communities feel their days are numbered. According to one Lakewood resident,

I've got three blacks \{families\} on my block, right now ... and well, you know the problem with blacks, they have friends, and they have visitors. That is the problem. We can't encourage our people to stay if this keeps up. Our housing stock has stayed pretty solid, but some people can't be encouraged much more to stay" (quoted in Brill, 1996, 110). 
The complexion of Orange County, particularly the inland areas, has changed considerably, as the number of Latinos and Asian/Pacific Islanders has grown. Nonetheless, blacks still constitute only 1.8 percent of the population (Roseman and Lee, 1998, 208). The net result of all these shifts is that although people of color can now be found throughout the region, they are concentrated in the mature suburbs, the eastern San Fernando Valley, and the San Gabriel Valley ${ }^{25}$. Central Los Angeles remains almost completely nonwhite, and whites continue to congregate along the periphery.

As Figures 2-4 suggest, many of the industries and land-uses associated with environmental hazards are concentrated in central Los Angeles, and, to a lesser extent, along industrial arteries. Both blacks and Latinos are disproportionately exposed, but for somewhat different reasons. As the most segregated population, black Angelenos were confined to south Los Angeles beginning in the 1920s (De Graff, 1970). While many blacks have left, south Los Angeles is still heavily black (Allen and Turner, 1997, 62), and contains portions of an old industrial corridor. Despite the fact that blacks were only intermittently hired in them, south Los Angeles housed many Fordist industries, the majority of which left in the 1970s and 1980s (Oliver et al., 1993, 122). This "rust belt" not only harbors various environmental hazards but, as a politically weak and industrially oriented area, attracts projects like incinerators and the proposed Pacific Pipeline (Aspen Environmental Group, 1993). Thus, blacks' exposure to environmental hazards is largely a function of severe spatial containment and the historic practice of locating hazardous land uses in black areas.

In contrast, Latinos' exposure is more a function of their role as low-wage labor within the racialized division of labor and the historic relationship between the barrio and industry. Latinos have always lived close to industry, but unlike blacks, they have, at times, been hired in large numbers (Morales and Ong, 1993; Ong and Blumenberg, 1993). Latinos' contemporary exposure cannot be understood outside of industrial and immigration shifts. Over the last twenty years, the region has undergone a simultaneous industrial decline and expansion (Soja, 1989, 200). While the finance and service sectors have grown dramatically, manufacturing declined in Los Angeles in the 1980s. In the 1990s, however, a selective reindustrialization was realized (Scott, 1996a) by high-technology industries and low-wage Latino labor. As a result, Latinos live near industry, since both are concentrated in central Los Angeles and industrial corridors, and they are exposed to hazards on the job (Ong and Blumenberg, 1993). Thus, their exposure is a function of their class and immigrant status, as well as their racial position. As Latinos, they live where brown and black people have historically lived, or in spaces vacated by the white working class.

${ }^{25}$ This is in keeping with studies suggesting that despite the growing presence of people of color in suburbia, they remain segregated and live in more marginal suburbs (Phelan and Schneider, 1996). 
Environmental hazards are concentrated in central Los Angeles (including the inner suburbs) in several distinct ways. First, because a significant portion of these communities are industrially zoned, industry continues to locate there (Cordoba Corp., 1987, 22). Yet because of the poverty of central Los Angeles and its land fragmentation and poor services, few of the large, well-financed firms in growth sectors move there ${ }^{26}$. Instead, small polluting activities and large-scale hazards, such as incinerators, are drawn to these areas, as "cleaner industries are dissuaded from locating in the area because of the toxic contamination" (LA Design Action Planning Team, 1990, 12). According to one official from Paramount, an inner suburb, "we provide a place for industry that nobody wants" (Carbajal in Flanigan, 1999). Scott has pointed out that low-technology, labor-intensive industries are now clustered near downtown; metallurgical and machinery industries are found in old industrial zones throughout the region, including the eastern San Fernando Valley, South Central, and northern Orange County; and high-technology industries are located on the fringe (1996a, 220-21; see also Kaplan, 1998).

Consider the Eastside and Southeast Planning Districts in the city of Los Angeles. In both cases, 20 percent of the land is zoned as industrial (City of Los Angeles Department of City Planning, 1988, 9; Garrow et al., 1987, 54). Not surprisingly, both of these communities were targets for incinerator projects in the 1980s. The City of Los Angeles proposed a waste-to-energy incinerator for South Central, but Concerned Citizens of South Central, a group of largely African American women, successfully resisted the project. In the second case, the city of Vernon, adjacent to Boyle Heights, proposed a hazardous waste incinerator. This time, the City of Los Angeles assisted the Mothers of East L.A. in defeating the project (Blumberg and Gottlieb, 1989).

Conflicting land uses are also a serious problem that intensifies potential environmental hazards. One planning document described the eastside as consisting of:

small, older, single family homes situated between or adjacent to large commercial and industrial buildings. ... The noise, dirt, heavy truck and trailer traffic along industrial/residential edges also severely detracts from the quality of life of nearby residents. Views from homes to loading docks, auto wrecking and repair yards, and heavy machinery do not provide the amenities traditionally associated with residential life (Garrow et al., 1987, 54).

eyond the general unsightliness, such land uses pose a severe threat to residents. Because of the lack of buffers and the hazardous nature of industry, there have been mass evacuations, school contaminations (Frammolino, 1999), explosions (Sahagun,

\footnotetext{
${ }^{26}$ Indeed, the eastside, south central, and northeast corner of the San Fernando Valley have all been designated as Enterprise Zones, in the hopes of attracting economic development.
} 
1989), potential cancer clusters (Gold, 1999), and workers killed (Malnic and Ramos, 1997). Newer suburban communities do not have the same concentration of hazardous industrial activities, and enjoy more effective zoning and land-use regulations. Overall, there are simply fewer pollution clusters along the coast (see Figures 2-4). With the exception of the port, coastal communities are cleaner (and whiter) than the central city. Besides the fact that the suburbs house better capitalized firms more likely to have the best available technology, the coastal breeze blows pollution inland, thus further cleansing the coastal suburbs.

In short, looking at the region as a whole, it is clear that people of color are disproportionately exposed to a particular set of environmental hazards. Such patterns are not the result of any single decision or particular act. Instead, they are the result of urban development in a highly racialized society over the course of 150 years.

\section{Conclusion}

I have argued that restrictive conceptions of racism characterize the environmental racism literature. In particular, the emphasis on siting, intentionality, and scale have contributed to conceptualizing both racism and space as discrete objects, rather than as social relations. These dominant conceptions are problematic because they prevent us from understanding how racism shapes places and the relationships between places, and thereby limits our ability to detect environmental racism. I have sought to challenge this approach by employing the concept of white privilege, which offers a more structural and spatial understanding of racism. Such a shift requires acknowledging that multiple forms of racism exist, including less conscious forms not characterized by malicious intent and hostility. White privilege allows us to see how environmental racism has been produced - not only by consciously targeting people of color (as in the incinerator cases) - but by the larger processes of urban development, including white flight, in which whites have sought to fully exploit the benefits of their whiteness.

In urban areas, explanations of environmental inequality must include careful consideration of residential patterns, land use, and industrial development. The history of suburbanization reveals that although many forces contributed to decentralization, it has largely been an exclusionary undertaking. Moreover, the state has played a central role in crafting such opportunities, choices, and landscapes. Although, in Los Angeles, nonwhites have always lived adjacent to industry, people of color have recently begun moving into the suburbs, and have taken over what were once white industrial suburbs. Over time, these industrial suburbs have become part of the inner city, and are increasingly populated by people of color. As a result, central Los Angeles with its concentration of industrial hazards, remains a nonwhite space. In contrast, whites continue to move to the periphery, which is relatively cleaner. These patterns 
developed over a century and continue to inform the present, illustrating how various forms of racism shape our landscapes.

This paper raises a host of policy, scholarly, and political issues. From a policy perspective, I have argued for the need to direct more attention to industrial zones and pollution clusters, rather than just the siting process and individual facilities. While the latter are clearly important, particularly in terms of future pollution, most industrial pollution does not involve new sitings, but is the product of already existing facilities, land uses, and zoning.

Scholarship on environmental racism can also be strengthened. It is essential that researchers begin to situate their work in terms of a larger sociospatial dialectic. Such a move would not only illuminate the geographic and historical context in which these patterns developed, but would also help us appreciate the extent to which places are shaped by various forms of racism. Relatedly, the fact that many geographers are hesitant to pursue these avenues of research underscores the need for greater breadth within our discipline and the limitations of specialization. As a discipline that is intimately associated with both human-environment relations and the study of space, we should be at the forefront of contributing new theoretical, empirical, and technical insights on the topic of environmental justice.

The issue of racism itself raises both scholarly and political concerns. I believe that as geographers, we need to diversify and deepen our approach to the study of racial inequality. Our traditional emphasis on mapping and counting needs to be complemented by research that seeks to understand what race means to people and how racism shapes lives and places. For instance, within the field of environmental racism, a key question that has not been seriously addressed is differential exposure. In other words, how might different experiences and histories of racism result in distinct geographies of exposure, say for instance, between the Shoshone nation, rural Blacks in the South, and an urban Asian American community in the San Francisco Bay area? Not only are such questions important in and of themselves, but they would help geography build bridges to other disciplines, such as ethnic studies.

But the question of racism within the discipline goes beyond research. And, as I have shown, our approach to the subject, unfortunately, speaks volumes about the collective politics of our discipline. What are we to make of a body of literature that purports to address the question of racism but is estranged from mainstream scholarly understandings of racism? Why do so many scholars cling to such a narrow conception of racism? What are the consequences of such an approach in terms of our research, teaching, and political efficacy? Perhaps a serious interrogation on the subject of racism is in order. At the very least, I hope that this paper demonstrates how individual scholars contribute to the reproduction of larger discourses and conceptions of race regardless of their motives. The point is not to lay blame, but to become aware of the larger political and moral consequences of our actions. 


\section{References}

Adeola, F. 1994. Environmental hazards, health, and racial inequity in hazardous waste distribution. Environment \& Behavior 26, 99-126.

Allen, J. and E. Turner. 1997. The Ethnic Quilt: Population Diversity in Southern California. Northridge: Center for Geographical Studies, California State University Northridge.

Almaguer, T. 1994. Racial Fault Lines: The Historical Origins of White Supremacy in California. Berkeley: University of California Press.

Anderson, K. 1987. The idea of Chinatown: The power of place and institutional practice in the making of a racial category. Annals of the Association of American Geographers 77, 580-98.

Anderson, S. 1996. A city called heaven. In, A. Scott \& E. Soja (eds.), The City. Berkeley: University of California Press, pp. 336-64.

Anderton, D., A. Anderson, P. Rossi, J. Oakes, M. Fraser, E. Weber and E. Calabrese. 1994a. Hazardous waste facilities: "Environmental equity" issues in metropolitan areas. Evaluation Review 18, 123-40.

Anderton, D., A. Anderson, J. Oakes and M. Fraser. 1994b. Environmental equity: The demographics of dumping. Demography 31, 229-48.

Armour, J. 1997. Negrophobia and Reasonable Racism. New York: New York University Press.

Arnold, C. 1998. Planning Milagros: Environmental justice and land use regulation. Denver University Law Review 76(1), 1-153.

Aspen Environmental Group. 1993. Pacific Pipeline Project: Draft Environmental Impact Report, Executive Summary. California Public Utilities Commission.

Avila, E. 1998. The folklore of the freeway: Space, culture, and identity in postwar Los Angeles. Aztlan 23(1), 15-32.

Babcock, R. and F. Bosselman. 1973. Exclusionary Zoning. New York: Praeger Publishers.

Baden, B. and D. Coursey. 1997. The Locality of Waste Sites within the City of Chicago: A Demographic, Social and Economic Analysis. Working paper series 97-2. Chicago: Irving B. Harris Graduate School of Public Policy Studies, University of Chicago. 
Banks, F. 1956. Industry puts up $\$ 190,000,000$. Midwinter: Los Angeles Times $75^{\text {th }}$ Anniversary, January 3, part 1, 63-64.

Bean v. Southwestern Waste Management Corporation. 1979. 482 F. Supp. 673. S.D. Tex.

Been, V. 1995. Analyzing evidence of environmental justice. Journal of Land Use and Environmental Law 11(1), 1-36.

Been, V. 1994. Locally undesirable land uses in minority neighborhoods: disproportionate siting or market dynamics? Yale Law Journal 103, 1383-422.

Been, V. 1993. What's fairness got to do with it? Environmental justice and the siting of locally undesirable land uses. Cornell Law Review 78,1001-85.

Berry, B. (ed.). 1977. The Social Burdens of Environmental Pollution: A Comparative Metropolitan Data Source. Cambridge, MA: Ballinger Publications.

Blumberg, L. and B. Gottlieb. 1989. Saying no to mass burn. Environmental Action January/February, 28-30.

Boer, J., J. Sadd, M. Pastor and L. Snyder. 1997. Is there environmental racism? The demographics of hazardous waste in Los Angeles County. Social Science Quarterly 78, 793-810.

Boerner, C. and T. Lambert. 1994. Environmental Justice? Policy Study 21. St. Louis: Center for the Study of American Business.

Bowden, T. and D. Mayborn. 1939. Confidentiality Report of a Survey in Metropolitan Los Angeles, California. For the Division of Research and Statistics, Home Owners Loan Corporation. Records Relating to the City Survey Files, 1935-40, Record Group 95, Box 101. National Archives and Records Administration, College Park, MD.

Bowen, W., M. Salling, K. Haynes and E. Cyran. 1995. Toward environmental justice: Spatial equity in Ohio and Cleveland. Annals of the Association of American Geographers 85, 641-63.

Brill, A. 1996. Lakewood, California "Tomorrowland" at 40. In, M. Dear, E. Schockman, \& G. Hise (eds.), Rethinking Los Angeles. Thousand Oaks, CA: Sage, pp. 97-112.

Brodkin, K. 1998. How Jews Became White Folks. New Brunswick, NJ: Rutgers University Press.

Bullard, R. 1996. Environmental justice: It's more than waste facility siting. Social Science Quarterly 77, 493-99. 
Bullard, R. 1994. Overcoming racism in environmental decision making. Environment 36(4), 10-20, 39-44.

Bullard, R. 1990. Dumping in Dixie. Boulder, CO: Westview Press.

Burke, L. 1993. Environmental Equity in Los Angeles. Master's thesis, Department of Geography, University of California, Santa Barbara.

California Department of Employment, Research and Statistics Division. 1960. Community Labor Market Surveys. California Historical Society, Los Angeles (LA) Area Chamber of Commerce Collection, Special Collections, Box 71. University of Southern California.

California Department of Employment, Research and Statistics Division .1952. Community Labor Market Surveys. California Historical Society, LA Area Chamber of Commerce Collection, Box 71. University of Southern California.

Cheng, L. and Yang, P. 1996. Asians: The "model minority" deconstructed. In, R. Waldinger \& M. Bozorgmehr (eds.), Ethnic Los Angeles. New York: Russell Sage Foundation, pp. 305-44.

City of Los Angeles, Department of City Planning. 1988. Southeast Los Angeles District Plan.

Cohan, C. 1956. Southland Building at New Peak. Midwinter: Los Angeles Times $75^{\text {th }}$ Anniversary. January 3, 44-5.

Cohen, P. 1992. "It's racism what dunnit": Hidden narratives in theories of racism. In, J. Donald \& A. Rattansi (eds.), Race, Culture and Difference. Newbury Park, CA: Sage, pp. 62-103.

Colten, C. 1986. Industrial wastes in Southeast Chicago: Production and disposal, 1870-1970. Environmental Review 10, 93-106.

Cordoba Corp. 1987. Final Application, Eastside Employment Incentive Area. Los Angeles: Community Development Department, City of Los Angeles.

Crenshaw, K., N. Gotanda, G. Peller and K. Thomas (eds.). 1995. Critical Race Theory. New York: New Press.

Cutter, S. 1995. Race, class and environmental justice. Progress in Human Geography 19, 107-18.

Cutter, S. 1994. The burdens of toxic risks: Are they fair? B \& E Review OctoberDecember, 3-7. 
Cutter, S. and W. Solecki. 1996. Setting environmental justice in space and place: Acute and chronic airborne toxic releases in the Southeastern U.S. Urban Geography 17, 380-99.

Cutter, S. and M. Tiefenbacher. 1991. Chemical hazards in urban America. Urban Geography 12, 417-30.

Davis, M. 1992. City of Quartz. New York: Vintage Books.

De Graff, L. 1970. The city of black angels: Emergence of the Los Angeles ghetto, 1890-1930. Pacific Historical Review 39, 323-52.

Dear, M. and S. Flusty. 1998. Postmodern urbanism. Annals of the Association of American Geographers 88, 50-72.

Delgado, R. 1995. The Rodrigo Chronicles. New York: New York University Press.

Devine, P. 1989. Stereotypes and prejudice: Their automatic and controlled components. Personality and Social Psychology 56, 5-18.

Doti, L. and L. Schweikart. 1989. Financing the postwar housing boom in Phoenix and Los Angeles, 1945-1960. Pacific Historical Review 58, 173-91.

East Bibb Twigs Neighborhood Assn. v. Macon-Bibb County Planning and Zoning Commission. 1989. 888 F. 2d 1573 (11th Cir.).

Ebner, M. 1987. Re-reading suburban America: Urban population deconcentration, 1810-1980. In, H. Gillette, Jr. \& Z. Miller (eds.), American Urbanism. Westport, CT: Greenwood Press, pp. 227-42.

Edsall, T., and M. Edsall. 1991. Chain Reaction. New York: W. W. Norton.

Fanon, F. 1967. Black Skins, White Masks. New York: Grove Press.

Fishman, R. 1987. Bourgeois Utopias. New York: Basic Books.

Flanigan, J. 1999. Downey takes lead to revive gateway cities. Los Angeles Times, June 16, C1, C4.

Fogelson, R. 1993. The Fragmented Metropolis: Los Angeles, 1850-1930. Berkeley: University of California Press.

Foner, E. 1974. Organized Labor and the Black Worker, 1619-1973. New York: International.

Frammolino, R. 1999. Report lists L.A. schools that pose toxic risks. Los Angeles Times, June 26, B1, B5. 
Frankenberg, R. 1993. White Women, Race Matters. Minneapolis: University of Minnesota.

Fredrickson, G. 1981. White Supremacy: A Comparative Study of Race in American and South African History. New York: Oxford University Press.

Frey, W., and Liaw, K. 1998. Immigrant concentration and domestic migrant dispersal: Is movement to nonmetropolitan areas "white flight"? The Professional Geographer 50, 215-32.

Garreau, J. 1991. Edge City: Life on the New Frontier. New York: Doubleday.

Garrow, P., J. Lau and S. Loong. 1987. Urban Ecology and Design for the Eastside Employment Incentive Area. Los Angeles: Department of City Planning.

Gilmore, R. 1998. Globalisation and U.S. prison growth: From military Keynesianism to Post-Keynesian militarism. Race \& Class 40(2/3), 171-88.

Gold, M. 1999. A School, factories and plenty of fear. Los Angeles Times, February 27, A1, A20, A21.

Goldberg, T. 1993. Racist Culture. Cambridge, MA: Blackwell.

Goldman, B. 1996. What is the future of environmental justice? Antipode 28, 122-41.

Gottdiener, M. and M. Kephart. 1995. The multinucleated metropolitan region: A comparative analysis. In, R. Kling, S. Olin \& M. Poster (eds.), Postsuburban California. Berkeley: University of California Press, pp. 31-54.

Guhathakurta, S. and M. Wichert. 1998. Who pays for growth in the City of Phoenix: An Equity-based perspective on suburbanization. Urban Affairs Review 33, 81338 .

Hamilton, J. 1995. Testing for environmental racism: Prejudice, profits, political power? Journal of Policy Analysis and Management 14, 107-32.

Harris, C. 1993. Whiteness as property. Harvard Law Review 106, 1709-91.

Harvey, D. 1985. The Urbanization of Capital. Baltimore: Johns Hopkins University Press.

Heiman, M. 1990. From "Not in my backyard!” to "not in anybody's backyard!": Grassroots challenges to hazardous waste facility siting. American Planning Association Journal 56, 359-62.

Hird, J. 1993. Environmental policy and equity: The case of superfund. Journal of Policy Analysis and Management 12, 323-43. 
Hise, G. 2001. "Nature's workshop": Industry and urban expansion in Southern California, 1900-1950. Journal of Historical Geography 27(1), 74-92.

Hise, G. 1998. Magnetic Los Angeles. Baltimore: Johns Hopkins University Press.

Hise, G. 1993. Home building and industrial decentralization in Los Angeles: The roots of the postwar urban region. Journal of Urban History 19(2), 95-125.

Horne, G. 1995. Fire This Time: The Watts Uprising and the 1960s. Charlottesville: University Press of Virginia.

Hurley, A. 1988. The social biases of environmental change in Gary, Indiana, 19451980. Environmental Review 12(4), 1-19.

Ignatiev, N. 1995. How the Irish Became White. New York: Routledge.

Jackson, K. 1980. Race, ethnicity, and real estate appraisal: The home owners loan corporation and the federal housing administration. Journal of Urban History 4, 419-52.

Jackson, P. and J. Penrose (ed.). 1994. Constructions of Race, Place, and Nation. Minneapolis: University of Minnesota.

Johnson, J. and C. Roseman. 1990. Increasing Black outmigration from Los Angeles: The role of household dynamics and kinship systems. Annals of the Association of American Geographers 80, 205-22.

Kaplan, K. 1998. Tech coast: Entrepreneurs and officials seek to ride an innovation wave to rival that of Silicon Valley. Los Angeles Times, March 9, D1, D12.

Kay, J. 1994. California's endangered communities of color. In, R. Bullard (ed.), Unequal Protection. San Francisco: Sierra Club Books, pp. 155-88.

Kirschenman, J. and K. Neckerman. 1991. We'd love to hire them, but ... The meaning of race for employers. In, C. Jenks \& P. Peterson (eds.), The Urban Underclass. Washington: Brookings Institution, pp. 203-32.

Kling, R., S. Olin and M. Poster. 1995. The emergence of postsuburbia: An introduction. In, R. Kling, S. Olin \& M. Poster (eds.), Postsuburban California. Berkeley: University of California Press, pp. 1-30.

Kobayashi, A., and L. Peake. 1994. Unnatural discourse: "race" and gender in Geography. Gender, Place \& Culture 1, 225-44.

Krieg, E. 1995. A Socio-Historical interpretation of toxic waste sites: The case of Greater Boston. American Journal of Economics and Sociology 54, 1-14. 
LA Design Action Planning Team. 1990. Boyle Heights, Los Angeles. Planning Department, Box C1518, Los Angeles City Archive.

Law, R., J. Wolch and L. Takahashi. 1993. Defenseless territory: Workers, communities, and the decline of military production in Los Angeles. Environment and Planning C: Government and Policy 11, 291-315.

Lawrence, C. 1987. The Id, the ego and equal protection: Reckoning with unconscious racism. Stanford Law Review 39, 317-88.

Lester, J., D. Allen and D. Milburn-Lauer. 1994. Race, Class, and Environmental Quality: An Examination of Environmental Racism in the American States. Paper presented at the Annual Meeting of the Western Political Science Association, Albuquerque.

Lipsitz, G. 1998. The Possessive Investment in Whiteness. Philadelphia: Temple University Press.

Lipsitz, G. 1995. The possessive investment in whiteness: Racialized social democracy and the "white" problem in American Studies. American Quarterly 47, 369-87.

Lockheed Aircraft Corporation. 1953. 168 communities contribute to Lockheed leadership. The Los Angeles Times Annual Midwinter, January 2. California Historical Society, LA Area Chamber of Commerce Collection, Box 118. University of Southern California.

Los Angeles Central Manufacturing District. 1923. Central Manufacturing District of Los Angeles. California Historical Society, LA Area Chamber of Commerce Collection, University of Southern California.

Los Angeles Chamber of Commerce. 1964. The Researcher: 1964 Statistical Summary. California Historical Society, LA Area Chamber of Commerce Collection, Box 64. University of Southern California.

Los Angeles Chamber of Commerce. Industrial Department. 1934. General Industrial Report of Los Angeles County, California. California Historical Society, LA Area Chamber of Commerce Collection, Special Collections, University of Southern California.

Los Angeles Chamber of Commerce. 1929. General Industrial Report of Los Angeles

County, CA and Surrounding Communities. California Historical Society, LA Area Chamber of Commerce Collection, Special Collections, University of Southern California. 
Los Angeles Chamber of Commerce. 1926. Facts about Industrial Los Angeles: Nature's Workshop. California Historical Society, LA Area Chamber of Commerce Collection, Special Collections, University of Southern California.

Los Angeles Chamber of Commerce. 1925. Industrial Communities of Los Angeles Metropolitan Area. California Historical Society, LA Area Chamber of Commerce Collection, Special Collections, University of Southern California.

Los Angeles 1965: Market and Media. 1965. Los Angeles Times. California Historical Society, LA Area Chamber of Commerce Collection, Box 118. University of Southern California.

Malnic, E. and Ramos, G. 1997. Explosion kills 4, injures 25 at L.A. toy factory. Los Angeles Times, November 6, A1, A30, A31.

Massey, D. 1994. Space, Place, and Gender. Minneapolis: University of Minnesota Press.

Massey, D. and N. Denton. 1993. American Apartheid: Segregation and the Making of the Underclass. Cambridge: Harvard University Press.

McGurty, E. 1995. The Construction of Environmental Justice: Warren County North Carolina. Ph.D. dissertation. University of Illinois, Urbana-Champaign.

Miller, G. 1981. Cities by Contract: The Politics of Municipal Incorporation. Cambridge: MIT Press.

Mohai, P. and B. Bryant. 1992. Environmental racism: Reviewing the evidence. In, B. Bryant \& P. Mohai (eds.), Race and the Incidence of Environmental Hazards. Boulder, CO: Westview Press, pp. 163-246.

Morales, R. and P. Ong. 1993. The illusion of progress: Latinos in Los Angeles. In, R. Morales \& F. Bonilla (eds.), Latinos in a Changing Economy. Newbury Park, CA: Sage, pp. 55-84.

Morrison, P. and R. Lowry. 1994. A riot of color: The demographic setting. In, M. Baldassare (ed.), The Los Angeles Riots. Boulder, CO: Westview Press, pp. 1946.

Myrdal, G. 1944. An American Dilemma: The Negro Problem and Modern Democracy. New York: Harper and Row.

Napton, M. and F. Day. 1992. Polluted neighborhoods in Texas, who lives there? Environment \& Behavior 24:508-26.

Newton, M. 1998. L.A. to get \$3.3 million for pollution cleanup. Los Angeles Times, March 18, B1, B8. 
Oliver, M. and Shapiro, T. 1995. Black Wealth, White Wealth. New York: Routledge.

Oliver, M., J. Johnson and W. Farrell. 1993. Anatomy of a rebellion: A politicaleconomic analysis. In, R. Gooding-Williams (ed.), Reading Rodney King, Reading Urban Uprising. New York: Routledge, pp. 117-41.

Omi, M. 1992. Shifting the blame: Racial ideology and politics in the post-civil rights era. Critical Sociology 18, 77-98.

Omi, M. and H. Winant. 1994. Racial Formation in the United States. New York: Routledge.

Ong, P. and E. Blumenberg. 1993. An unnatural trade-off: Latinos and environmental justice. In, R. Morales \& F. Bonilla (eds.), Latinos in a Changing U.S. Economy. Newbury Park, CA: Sage, pp. 207-25.

Parson, D. 1984. Organized labor and the housing question: Public housing, suburbanization and urban renewal. Society and Space 1, 75-86.

Perlin, S., R. Setzer, J. Creason and K. Sexton. 1995. Distribution of industrial air emissions by income and race in the United States: An approach using the toxic release inventory. Environmental Science Technology 29(1), 69-80.

Phelan, T. and M. Schneider. 1996. Race, ethnicity, and class in American suburbs. Urban Affairs Review 31, 659-80.

Pollock, P. and M. Vittas. 1995. Who bears the burdens of environmental pollution? Race, ethnicity and environmental equity in Florida. Social Science Quarterly $76,294-310$.

Pulido, L. 1996. A critical review of the methodology of environmental racism research. Antipode 28(2), 142-59.

Pulido, L., S. Sidawi and R. Vos. 1996. An archaeology of environmental racism in Los Angeles. Urban Geography 17(5), 419-39.

Quadagno, J. 1994. The Color of Welfare. New York: Oxford University Press.

Roediger, D. 1991. The Wages of Whiteness. New York: Verso.

Romo, R. 1983. History of a Barrio: East Los Angeles. Austin: University of Texas Press.

Roseman, C. and S. Lee. 1998. Linked and independent African American migration from Los Angeles. The Professional Geographer 50, 204-14. 
Sabagh, G. and M. Bozorgmehr. 1996. Population change: Immigration and ethnic transformation. In, R. Waldinger \& M. Bozorgmehr (eds.), Ethnic Los Angeles. New York: Sage, pp. 79-107.

Sadd, J., M. Pastor, J. Boer and L. Snyder. 1999. Every breath you take ... The demographics of point source air pollution in Southern California. Economic Development Quarterly 13(2), 107-23.

Sahagun, L. 1989. Toxic neighbors: Measure would force metal platers out of residential areas. Los Angeles Times, August 28, Metro 1, 6.

Sanchez, G. 1993. Becoming Mexican American: Ethnicity, Culture and Identity in Chicano Los Angeles, 1900-1945. New York: Oxford.

Saxton, A. 1971. The Indispensable Enemy. Berkeley: University of California Press.

Schiesl, M. 1995. Designing the model community: The Irvine Company and suburban development, 1950-88. In, R. Kling, S. Olin \& M. Poster (eds.). Postsuburban California. Berkeley: University of California Press, pp. 55-91.

Scott, A. 1996a. The manufacturing economy: Ethnic and gender divisions of labor. In, R. Waldinger \& M. Bozorgmehr (eds.), Ethnic Los Angeles. New York: Sage, pp. 215-44.

Scott, A. 1996b. High technology industrial development in the San Fernando Valley and Ventura County. In, A. Scott \& E. Soja (eds.), The City. Berkeley: University of California Press, pp. 276-310.

Scott, A. 1990. Metropolis: From Division of Labor to Urban Form. Berkeley: University of California Press.

Scott, M., S. Cutter, C. Menzel and J. Minhe. 1997. Spatial accuracy of the EPA's environmental hazards databases and their use in environmental equity analysis. Applied Geographic Studies 1(1), 45-61.

Sharpe, W. and Wallock, L. 1994. Bold new city or built up 'burb? Redefining contemporary suburbia. American Quarterly 46, 1-30.

Smith, N. 1993. Homeless/global: Scaling places. In, J. Bird, B. Curtis, T. Putnam \& G. Robertson (eds.), Mapping the Futures: Local Cultures, Global Change. London: Routledge, pp. 87-119.

Smith, S. 1993. Residential segregation and the politics of racialization. In, M. Cross \& M. Keith (eds.), Racism, the City, and the State. New York: Routledge, pp. 12843. 
Soja, E. 1996. Los Angeles, 1965-1992: From crisis-generated restructuring to restructured-generated crisis. In, A. Scott \& E. Soja (eds.), The City. Berkeley: University of California Press, pp. 426-62.

Soja, E.1989. Postmodern Geographies. New York: Verso.

Szasz, A. and M. Meuser. 1997. environmental inequalities: Literature review and proposals for new directions in research and theory. Current Sociology 45(3), 99120.

Szasz, A., M. Meuser, H. Aronson and H. Fukarai. 1993. The Demographics of Proximity to Toxic Releases: The Case of Los Angeles County. Paper Presented at the Meetings of the American Sociological Association, Miami.

United Church of Christ, Commission for Racial Justice. 1987. Toxic Wastes and Race in the United States. New York: United Church of Christ.

U.S. Division of Research and Statistics. 1939. Federal Home Loan Bank Board. Residential Security Map. Sections 1-4. Record Group 95, Box 101. National Archives and Records Administration, College Park, MD.

U.S. General Accounting Office. 1995. Hazardous and Nonhazardous Waste: Demographics of People Living Near Waste Facilities. GAO/RCCD-95-84.

U.S. General Accounting Office.1984. Siting of Hazardous Waste Landfills and their Correlation with Racial and Economic Statusof Surrounding Communities. Washington: General Accounting Office.

Walker, R. 1981. A theory of suburbanization: Capitalism and the construction of urban space in the United States. In, M. Dear \& A. Scott (eds.), Urbanization and Urban Planning in Capitalist Society. New York: Methuen, pp. 383-429.

Warren, W. 1986-1987. Maps: A spatial approach to Japanese American communities in Los Angeles. Amerasia 13, 137-51.

Washington v. Davis. 1976. 426 U.S. 229, 96 S. Ct. 2040.

Weeks, P. 1963. 700 March for integration in Torrance Tract. Los Angeles Times, June $30,1,12$.

Woods, C. 1998. Arrested Development: Regional Planning in the Mississippi Delta. New York: Verso.

Yandle, T. and Burton, D. 1996. Reexamining environmental justice: A statistical analysis of historical waste landfill siting patterns in Metropolitan Texas. Social Science Quarterly 77, 477-92. 
Zimmerman, R. 1994. Issues of classification in environmental equity: How we manage is how we measure. Fordham Urban Law Journal 21(3), 633-69.

Zimmerman, R. 1993. Social equity and environmental risk. Risk Analysis 13, 649-66.

Zoning Map Company. 1930. The Los Angeles Zoning Atlas. California Historical Society, LA Area Chamber of Commerce Collection, Box 66, Special Collections, University of Southern California. 